\title{
Optimizing the Methylene Blue Removal from Aqueous Solution Using Pomelo Peel Based Biochar Assisted by RSM and ANN-PSO
}

\author{
Wenyun Wang ${ }^{1 *}$, Xianliang $\mathrm{Wu}^{2}$, Shengxing Long $^{3}$ \\ ${ }^{1}$ College of Biology and Environmental Engineering, Guiyang University, Guiyang 550001, Guizhou, China \\ ${ }^{2}$ Guizhou Institute of Biology, Guiyang, Guizhou 550009, China \\ ${ }^{3}$ College of Urban and Environmental Sciences, Peking University, Beijing 100871, China
}

Received: 29 March 2021

Accepted: 21 May 2021

\begin{abstract}
Biochar is regarded as an ideal adsorbent because of its low cost, high adsorption performance, large porosity and high carbon content, which can effectively adsorb organic pollutants in wastewater. The present study explores the modified pomelo peel based biochar used to remove methylene blue (MB) from the simulated wastewater and its adsorption mechanism. The calcinated biochar prepared by pomelo peel under the three temperatures $\left(450^{\circ} \mathrm{C}, 500^{\circ} \mathrm{C}\right.$ and $\left.550^{\circ} \mathrm{C}\right)$ was characterized using SEM, FI-IR, XRD, $\mathrm{N}_{2}$ adsorption and TGA. The removal conditions were optimized by response surface methodology (RSM) and artificial neural network-particle swarm optimization (ANN-PSO). The results showed that the bulk structure and surface rougher of the biochar increase with the rising of calcination temperature. The prepared materials contained a large number of active functional groups such as lignin, cellulose and hemicellulose. The specific surface area of the calcinated materials at $450^{\circ} \mathrm{C}, 500^{\circ} \mathrm{C}$ and $550^{\circ} \mathrm{C}$ is $2.511,3.353$ and $4.344 \mathrm{~m}^{2} / \mathrm{g}$, respectively, which were belong to mesoporous materials $(2-50 \mathrm{~nm})$. ANN-PSO was more suitable than that of RSM to optimize the removal conditions of $\mathrm{MB}$ using the prepared materials. The maximum removal efficiency of MB was reached at $89.72 \%$ under temperature $=34.63^{\circ} \mathrm{C}$, reaction time $=80.00 \mathrm{~min}$, initial $\mathrm{MB}$ concentration $=169.73 \mathrm{mg} / \mathrm{L}$ and initial $\mathrm{pH}=7$. The actual removal efficiency of verification experiment was $87.96 \%$, and the absolute error was $1.76 \%$. The process of MB adsorbed onto the prepared biochar was well accordant with the pseudo second-order kinetic and Langmuir models. The adsorption process of MB by the biochar was a spontaneous, endothermic and entropy-driven. In summary, it is thus indicated that the modified pomelo peel based biochar can be regenerated within fourth cycle and have application prospect as a useful adsorbent for water treatment.
\end{abstract}

Keywords: modified pomelo peel based biochar, methylene blue, response surface methodology, artificial neural network-particle swarm optimization, kinetic

*e-mail: wangwenyun1317@163.com 


\section{Introduction}

Methylene blue (MB), a kind of thiazine dye, was used early to cure cancer, bacterial and viral infections, and central nervous system diseases, etc [1-3]. Meanwhile, MB is employed in aquaculture to treat some fish diseases or as a disinfectant. Among them, the principle of the latter is that the ionic compound formed by methylene blue in aqueous solution can compete with microbial enzyme system for hydrogen ion (inactivating the enzyme), and thus reducing the microbial viability [4]. Since the 1990s, $\mathrm{MB}$, instead of malachite green and crystal violet, has been adopted in aquaculture to prevent and control water mold, Saimei, Cucurbita and other fish diseases, as well as in live fish transportation and environmental disinfection [5]. In addition, $\mathrm{MB}$ can be utilized to relieve cyanide, nitrite, aniline, acetanilide poisoning, or methemoglobinemia caused by sulfonamides and other drugs due to its redox properties [6]. Although MB has an excellent curative effect in the treatment of methemoglobin, it may lead to Heinz body anemia, morphological changes of red blood cells and necrotic edema if the dosage of methylene blue is too high [7]. It can produce a burning sensation through oral intake, and may cause nausea, vomiting, sweating, mental disorder and methemoglobinemia, etc [8]. At present, several countries or institutions, including USA, EU and Japan, have formulated for the detection of methylene blue residues in aquatic products. Unfortunately, there is no relevant regulation on the residue limit of methylene blue in China so far. Therefore, it is necessary to propose the feasible method to repair the wastewater containing the higher concentration of MB.

Hereto, many approaches have been developed to remove the higher concentration of MB from wastewater, of which adsorption is an efficiency and widespread measures for repairing the wastewater contaminated by MB [9]. Wang et al. [10] reported that the synthesized polyaniline/ $\mathrm{TiO}_{2}$ was applied in the adsorption of methylene blue (MB) to evaluate the adsorption performance of these materials for cationic dye. The results revealed that the adsorption of $\mathrm{MB}$ on polyaniline $/ \mathrm{TiO}_{2}$ was mainly controlled by chemical adsorption, membrane diffusion and intraparticle diffusion. The maximum adsorption capacity was $458.10 \mathrm{mg} / \mathrm{g}$. $\mathrm{HCl}$ solution $(0.1 \mathrm{~mol} / \mathrm{L})$ was used as stripping agent to study the regeneration stability of polyaniline $/ \mathrm{TiO}_{2}$, and the adsorption efficiency can be maintained over $99 \%$ after 10 cycles. Ghosh et al. [11] described that jute stick, an underexplored byproduct of jute cultivation system, has been used as a novel low-cost adsorbent to remove MB from aqueous medium. The optimum values of $\mathrm{pH}$, dose, initial concentration, and time for maximum MB removal were 10.27, $5(\mathrm{~g} / \mathrm{L}), 200(\mathrm{ml} / \mathrm{L})$ and $66.06 \mathrm{~min}$. $0.1 \mathrm{~mol} \mathrm{H}_{2} \mathrm{SO}_{4}$ was found suitable for regeneration and $\mathrm{MB}$ removal decreased up to $23.6 \%$ after three cycles. Zulfikar et al. [12] exhibited the potential use of natural rubber seeds to remove $\mathrm{MB}$ from aqueous solution. NRS was pretreated using epichlorohydrin and concentrated $\mathrm{H}_{2} \mathrm{SO}_{4}$ in various impregnation ratios to produce modified NRS called NRSEA. The results of MB adsorption ability test onto NRSEA showed that the adsorption capacity increased with increasing $\mathrm{pH}$ (within the $\mathrm{pH}$ range of 7-12) and decreased afterwards, the optimum initial MB concentration reached at $800 \mathrm{mg} / \mathrm{L}$, and the equilibrium state was achieved at $120 \mathrm{~min}$ of contact time. Enhanced methylene blue removal from aqueous solution using modified rubber seed (Hevea brasiliensis). Although many researchers have paid attention to the importance of MB removal from wastewater and several measures are carried out to solve the environmental issue, these adsorbents are not widely employed in practical application due to high cost of them. Therefore, it is urgent to seek an effective approach to removal MB from wastewater in practical application.

Many low-cost adsorbents have been proposed for MB removal from aqueous solution, including biosorbents and wastes from agriculture and industry $[13,14]$. Among them, biochar, a commonly used adsorbent, has a high adsorption performance and a good effect on wastewater adsorption in water environment [15]. Fan et al. [16] reported that biochar generated from municipal sludge and tea waste through co-pyrolysis was employed to remove MB. The results showed that pseudo-second order kinetics was the most suitable model for describing the adsorption of $\mathrm{MB}$ onto biochar. Equilibrium data were well fitted to the Langmuir isotherm model. The mechanism between MB and biochar involved electrostatic interaction, ion exchange, surface complexation, physical function and others. Lonappan et al. [17] exhibited that biochar microparticles were prepared from three different types of biochar, derived from waste materials, such as pine wood, pig manure and cardboard under various pyrolysis conditions. Biochar microparticles prepared from different sources exhibited improvement in adsorption capacity $(7.8 \pm 0.5 \mathrm{mg} / \mathrm{g}$ to $25 \pm 1.3 \mathrm{mg} / \mathrm{g})$ in comparison with raw biochar and commercially available activated carbon. The maximum adsorption capacity was $25 \mathrm{mg} / \mathrm{g}$ for biochar-pig manure microparticles at $25^{\circ} \mathrm{C}$ for an adsorbate concentration of $500 \mathrm{mg} / \mathrm{L}$ in comparison with $48.30 \pm 3.6 \mathrm{mg} / \mathrm{g}$ for activated carbon. Zhang et al. [18] found a green biochar/iron oxide composite was produced using a facile approach involving banana peel extract and $\mathrm{FeSO}_{4}$. The modified biochar's capacity to adsorb MB was considerably enhanced (Langmuir $\mathrm{Q}_{\max }$ of $862 \mathrm{mg} / \mathrm{g}$ for $\mathrm{MB}$ when $\mathrm{C}_{0}=500 \mathrm{mg} / \mathrm{L}$, $\mathrm{pH}=6.1, \mathrm{~T}=313 \mathrm{~K}$ ) compared to the unmodified banana peel biochar, and exhibited good performance for a wide range of $\mathrm{pH}$ values ( $\mathrm{pH}$ 2.05-9.21). The above mentioned studies demonstrate that biochar is an efficiency and low-cost adsorbent used to remove MB from wastewater. A large amount of pomelo peel was consumed every year in China, and its main sources are food and juice processing. Directly 
discarding pomelo peel will waste resources and pollute the environment. Hence, the biochar prepared by pomelo peel was a promising adsorbent to repair water polluted by MB.

Currently, many methods was used to optimize the operating parameters, including initial $\mathrm{pH}$, initial $\mathrm{MB}$ concentration, temperature, adsorbent doses, contact time, of contaminants removal from aqueous solutions. These approaches such as response surface methodology (RSM), artificial neural network (ANN), genetic algorithm (GA), particle swarm optimization (PSO) were successful employed in environmental remediation [19-21]. Consequently, the objective of this study is aim to use the pomelo peel based biochar activated by $\mathrm{MgCl}_{2}$ to remove $\mathrm{MB}$ from simulated wastewater. The experimental conditions were designed and optimized by box Behnken of response surface methodology. Meanwhile, the results of RSM optimization were compared with ANN-PSO. Finally, the adsorption mechanism was discussed by kinetics, adsorption isothermal and thermodynamics. The present study provides a theoretical basis for biochar used to removal organic pollutants from wastewater with the aid of artificial neuron network as well as preparing for pilotscale remediation combined with permeable reactive barrier in future work.

\section{Materials and Methods}

\section{Preparation of Modified Pomelo Peel Based \\ Biochar and Determination of Methylene Blue Concentration}

The pomelo peel used in this experiment is agricultural waste Shatian pomelo peel. Firstly, the pomelo peel was cut into pieces, cleaned with distilled water to remove the surface impurities, and dried in the drying oven at $80^{\circ} \mathrm{C}$ for $24 \mathrm{~h}$ to constant weight. Then, the pomelo peel was crushed into powder, which was passed through a 100 mesh sieve, and put into a dryer for standby. The dry powder of $40 \mathrm{~g}$ was put into a $500 \mathrm{~mL}$ beaker, and the absolute ethanol of $200 \mathrm{~mL}$ and $0.5 \mathrm{~mol} / \mathrm{L} \mathrm{NaOH}$ of $100 \mathrm{~mL}$ were added the above mentioned beaker. The mixtures were successively stirred for $30 \mathrm{~min}$, added $1.5 \mathrm{~mol} / \mathrm{L} \mathrm{MgCl}_{2}$ solution of $100 \mathrm{~mL}$ and soaked for $24 \mathrm{~h}$. Finally, the mixtures were filtered and washed with distilled water until the $\mathrm{pH}$ is neutral, and dried in $80^{\circ} \mathrm{C}$ drying oven for $24 \mathrm{~h}$. The dried pomelo peel of $10 \mathrm{~g}$ was weighed and put<smiles>CN(C)c1ccc2nc3ccc(=[N+](C)C)cc-3sc2c1</smiles>

Fig. 1. Structure of methylene blue. into a vacuum tube furnace. The temperature was programmed to $450^{\circ} \mathrm{C}, 500^{\circ} \mathrm{C}$ and $550^{\circ} \mathrm{C}$ at the rate of $2^{\circ} \mathrm{C} / \mathrm{min}$ and calcined for $3 \mathrm{~h}$. After the end of cooling, the biochar cracked at $450^{\circ} \mathrm{C}, 500^{\circ} \mathrm{C}$ and $550^{\circ} \mathrm{C}$ was obtained.

Methylene blue (molecular formula: $\mathrm{C}_{16} \mathrm{H}_{18} \mathrm{ClN}_{3} \mathrm{~S}$, molecular weight: 319.85 ) solution of $5 \mathrm{mg} / \mathrm{L}$ was prepared and scanned with UV-vis spectrophotometer in the wavelength range of 200-700 $\mathrm{nm}$ and its structure is showed as Fig. 1 [22]. The maximum absorption peak wavelength was selected in the present study, and the value was $665 \mathrm{~nm}$. The filtrate after adsorption experiment was poured into $1 \mathrm{~cm}$ cuvette, and the absorbance A of MB filtrate was determined at $665 \mathrm{~nm}$ by $722 \mathrm{~N}$ ultraviolet visible spectrophotometer. Based on $10 \mathrm{mg} / \mathrm{L} \mathrm{MB}$ solution, MB solutions of $0.5 \mathrm{mg} / \mathrm{L}$, $1.0 \mathrm{mg} / \mathrm{L}, 2.0 \mathrm{mg} / \mathrm{L}, 4.0 \mathrm{mg} / \mathrm{L}$ and $6.0 \mathrm{mg} / \mathrm{L}$ were prepared, respectively. With deionized water as reference, the absorbance of the above methylene blue solution was measured at the selected maximum wavelength of $665 \mathrm{~nm}$. The concentration $C$ was used as the horizontal standard, the absorbance $\mathrm{A}$ as the ordinate, the following standard curve and correlation linearity are $\mathrm{C}=0.16 \mathrm{~A}+0.0088\left(\mathrm{R}^{2}=0.9991\right)$.

\section{Adsorption Experiment}

\section{Effect of Single Factors on MB Adsorbed onto Biochar}

Four factors, including adsorption temperature, contact time, initial MB concentration methylene blue and initial $\mathrm{pH}$, were selected to study the effects of these factors in the process of modified pomelo peel based biochar adsorbed onto MB. A certain concentration of MB with a volumetric flask was prepared, and then a certain quality of the biochar powder was put into the solutions. The mixtures were put into a constant temperature oscillation box with vibrate at the rate of $120 \mathrm{r} / \mathrm{min}$ at room temperature, rendering that the biochar can fully contact with MB solution. After certain adsorption, the adsorption residue solutions were successively taken out, filtered and measured. Then, the equilibrium concentration of $\mathrm{MB}$ in the filtrate was calculated according to the following equations [23]:

$$
\begin{gathered}
Q=\frac{\left(C_{0}-C e\right) \times V}{M} \\
P=\frac{C_{0}-C e}{C_{0}} \times 100 \%
\end{gathered}
$$

...where $C_{0}$ is the MB concentration of solution before adsorption, $\mathrm{mg} / \mathrm{L} ; \mathrm{Ce}$ is the $\mathrm{MB}$ concentration of solution after adsorption, $\mathrm{mg} / \mathrm{L} ; M$ is the mass of solid adsorbent, $\mathrm{g} ; P$ is the equilibrium adsorption capacity of biochar, $\mathrm{mg} / \mathrm{g} ; V$ is volume of solution, $\mathrm{mL}$. 


\section{Effect of Biochar Dosages on MB Adsorbed onto Biochar}

The biochar samples prepared of $0.025 \mathrm{~g}, 0.050 \mathrm{~g}$, $0.100 \mathrm{~g}$ and $0.150 \mathrm{~g}$ were accurately weighed and put into $250 \mathrm{ml}$ conical flask, respectively. $20 \mathrm{mg} / \mathrm{L} \mathrm{MB}$ solutions of $50 \mathrm{~mL}$ were put into the above conical flask in turn, and these mixtures were oscillated at $25^{\circ} \mathrm{C}$ for $3 \mathrm{~h} \quad(120 \mathrm{r} / \mathrm{min})$. The samples are filtered with syringe and measured at $665 \mathrm{~nm}$ with $722 \mathrm{~N}$ UVVis spectrophotometer to calculate the capacity of MB adsorbed onto biochar.

\section{Pomelo Peel Biochar Prepared in Different Environment}

The $0.05 \mathrm{~g}$ of biochar cracked at $450^{\circ} \mathrm{C}$ in vacuum and nitrogen atmosphere was accurately weigh, respectively. $100 \mathrm{mg} / \mathrm{L} \mathrm{MB}$ solution of $50 \mathrm{~mL}$ was successively added into the conical flask and the mixtures were shake at $25^{\circ} \mathrm{C}$ for $3 \mathrm{~h}(120 \mathrm{r} / \mathrm{min})$. Then, the samples were filtered with syringe and measured at $665 \mathrm{~nm}$ with $722 \mathrm{~N}$ UV-Vis spectrophotometer.

\section{Biochar Prepared by Pomelo Peel at Different Pyrolysis Temperatures}

Pyrolysis can be divided into three basic forms, viz. slow, medium and fast pyrolysis. Their products and properties are different with the various pyrolysis temperature. In the present study, the $0.05 \mathrm{~g}$ biochar prepared in vacuum atmosphere at $450^{\circ} \mathrm{C}, 500^{\circ} \mathrm{C}$ and $550^{\circ} \mathrm{C}$ were put into $250 \mathrm{~mL}$ conical flask, respectively. 10 and $15 \mathrm{mg} / \mathrm{L} \mathrm{MB}$ solution of $50 \mathrm{~mL}$ were added into the above conical flask in turn, and the mixtures were shaken at $25^{\circ} \mathrm{C}$ for $3 \mathrm{~h}(120 \mathrm{r} / \mathrm{min})$.

\section{The Experimental Design of Response Surface Methodology and ANN-PSO}

The main effects and interactions of temperature, $\mathrm{pH}$, initial $\mathrm{MB}$ concentration and adsorbent dosage on MB removal were studied, and the range of adsorption conditions were optimized in the present study. The box Behnken response surface was used to optimize the experimental design. The central point experiment was five parallel experiments and the experimental design of 4 factors- 3 levels is shown in Table 1. The quadratic polynomial model was the following [24]:

$$
f=\beta_{0}+\sum_{i=1}^{k} \beta_{i} x_{i}+\sum_{i=1}^{k} \beta_{i i}\left(x_{i}\right)^{2}+\sum_{i=1}^{k-1} \sum_{j=2}^{k} \beta_{i j} x_{i} x_{j}
$$

...where $f$ represents the removal percentage of arsenide in the present study; $x_{i}$ and $x_{\mathrm{j}}$ denote the coded levels of independent variables; the terms $x_{i} x_{j}$ and $\left(x_{i}\right)^{2}$ denote the interaction and quadratic terms, respectively; the terms $\beta_{0}, \beta_{\mathrm{i}}, \beta_{\mathrm{ii}}$ and $\beta_{\mathrm{ij}}$ denote the regression coefficients. Table 1 shows the independent variables and Box-Behnken experimental design used in this work.

Back propagation is a kind of multilayer feedforward neural network trained according to error back propagation algorithm, which is one of the most widely used neural networks [25]. However, BP has several defects, such as slow learning speed, easy to fall into local minimum, and no corresponding theoretical guidance for the selection of network layers and number of neurons [25]. Particle swarm optimization (PSO) algorithm, each particle in the particle swarm represents a possible solution of the problem, through the simple behavior of individual particles, information interaction within the group to achieve the intelligence of problem solving [26]. Because of its simple operation and fast convergence speed, PSO has been widely used in many fields, such as function optimization, image processing, geodes, etc. Therefore, combining both of them, ANN-PSO can be used to overcome the defects of BP (Fig. 2).

Suppose that in a d-dimensional target search space, there are $\mathrm{N}$ particles forming a community, in which the $i$ th particle is expressed as a d-dimensional vector.

$$
X_{i}=\left(x_{i 1}, x_{i 2}, x_{i 3} \cdots x_{i \mathrm{~d}}\right) \quad i=1,2, \cdots, \mathrm{N}
$$

The flight speed of the $i$ th particle is also a D-dimensional vector:

$$
V_{i}=\left(v_{i 1}, v_{i 2}, v_{i 3}, \cdots v_{i D}\right) \quad i=1,2, \cdots, N
$$

The optimal $\mathrm{V}$ position of the i-th particle is called individual extremum:

$$
P_{b e s t}=\left(p_{i 1}, p_{i 2}, p_{i 3}, \cdots p_{i \mathrm{~d}}\right) \quad i=1,2, \cdots, \mathrm{N}
$$

Hereto, the optimal location of the whole PSO is the global extremum:

Table 1. Level of parameters in Box-Behnken experimental design.

\begin{tabular}{|c|c|c|c|c|}
\hline Code & Parameter & Maximum & Middle & Minimum \\
\hline A & Contact time $(\mathrm{min})$ & 80 & 70 & 60 \\
\hline B & Initial MB concentration $(\mathrm{mg} / \mathrm{L})$ & 200 & 150 & 100 \\
\hline C & Temperature $\left({ }^{\circ} \mathrm{C}\right)$ & 40 & 25 & 20 \\
\hline D & Initial $\mathrm{pH}$ & 8 & 7 & 6 \\
\hline
\end{tabular}




$$
G_{\text {best }}=\left(p_{g 1}, p_{g 2}, p_{g 3}, \cdots p_{g \mathrm{D}}\right)
$$

When searching for individual and global extremum, the particle updates its position and velocity according to the following formula:

$$
\begin{gathered}
V_{i d}^{k}=w \times V_{i d}^{k-1}+c_{1} r_{1}\left(p_{i d}-x_{i d}^{k-1}\right)+c_{2} r_{2}\left(p_{g d}-x_{i d}^{k-1}\right) \\
x_{i d}^{k}=V_{i d}^{k}+x_{i d}^{k-1} \\
w=w_{\max } \times \frac{t \times\left(w_{\max }-w_{\min }\right)}{t_{\max }}
\end{gathered}
$$

...where $w$ is inertia weight (non negative number), which can adjust the search range of solution space. $C_{1}$ and $C_{2}$ are learning factors. $r_{1}$ and $r_{2}$ increase random search. The $w_{\max }$ is the maximum weight and $w_{\min }$ is the minimum weight; $t$ and $t_{\max }$ is the current and maximum number of iteration steps, respectively.

\section{Results and Discussion}

\section{Efferent of the Different Conditions on Removal MB Using the Modified Pomelo Peel Based Biochar}

Table 2 shows the adsorption capacity of $\mathrm{MB}$ decreases with the biochar dosage increases from $0.05 \mathrm{~g}$ to $0.15 \mathrm{~g}$. Therefore, $0.05 \mathrm{~g}$ was selected and used in this study. Table 3 exhibits that the adsorption effect
Table 2. Adsorption capacity of methylene blue by biological carbon prepared by pomelo peel.

\begin{tabular}{|c|c|c|c|}
\hline $\begin{array}{c}\text { Biochar } \\
\text { adsorbent }(\mathrm{g})\end{array}$ & $\mathrm{C}_{\mathrm{e}}(\mathrm{mg} / \mathrm{L})$ & $q_{\mathrm{e}}(\mathrm{mg} / \mathrm{g})$ & $\begin{array}{c}\text { Removal } \\
\text { efficiency }(\%)\end{array}$ \\
\hline 0.025 & 0.1625 & 19.8375 & $99 \%$ \\
\hline 0.05 & 0.1938 & 19.8063 & $99 \%$ \\
\hline 0.1 & 0.3563 & 19.6438 & $98 \%$ \\
\hline 0.15 & 0.5563 & 19.4438 & $97 \%$ \\
\hline
\end{tabular}

Table 3. Yield of biological carbon prepared by pomelo peel in different atmosphere.

\begin{tabular}{|c|c|c|}
\hline Samples & $q_{\mathrm{e}}(\mathrm{mg} / \mathrm{g})$ & $\begin{array}{c}\text { Removal } \\
\text { efficiency (\%) }\end{array}$ \\
\hline Vacuum atmosphere & 14.79 & $99 \%$ \\
\hline Nitrogen atmosphere & 14.61 & $97 \%$ \\
\hline
\end{tabular}

of $\mathrm{MB}$ by biochar prepared in vacuum atmosphere is better than that by biochar prepared in nitrogen atmosphere, hence, the biochar prepared in vacuum atmosphere is selected for the experiment. Table 4 exhibits that the efficiency of $\mathrm{MB}$ removal by biochar of cracking pomelo peel at $500^{\circ} \mathrm{C}$ is the highest, and the removal efficiency of biochar is decreased significantly at $500^{\circ} \mathrm{C}-550^{\circ} \mathrm{C}$. Under the same conditions, the order of adsorption capacity of $\mathrm{MB}$ on biochar at equilibrium is $500^{\circ} \mathrm{C}>450^{\circ} \mathrm{C}>550^{\circ} \mathrm{C}$. Therefore, the biochar obtained by cracking pomelo peel at $500^{\circ} \mathrm{C}$ was selected in the present study to ensure that the experiment was completed under the optimal conditions.
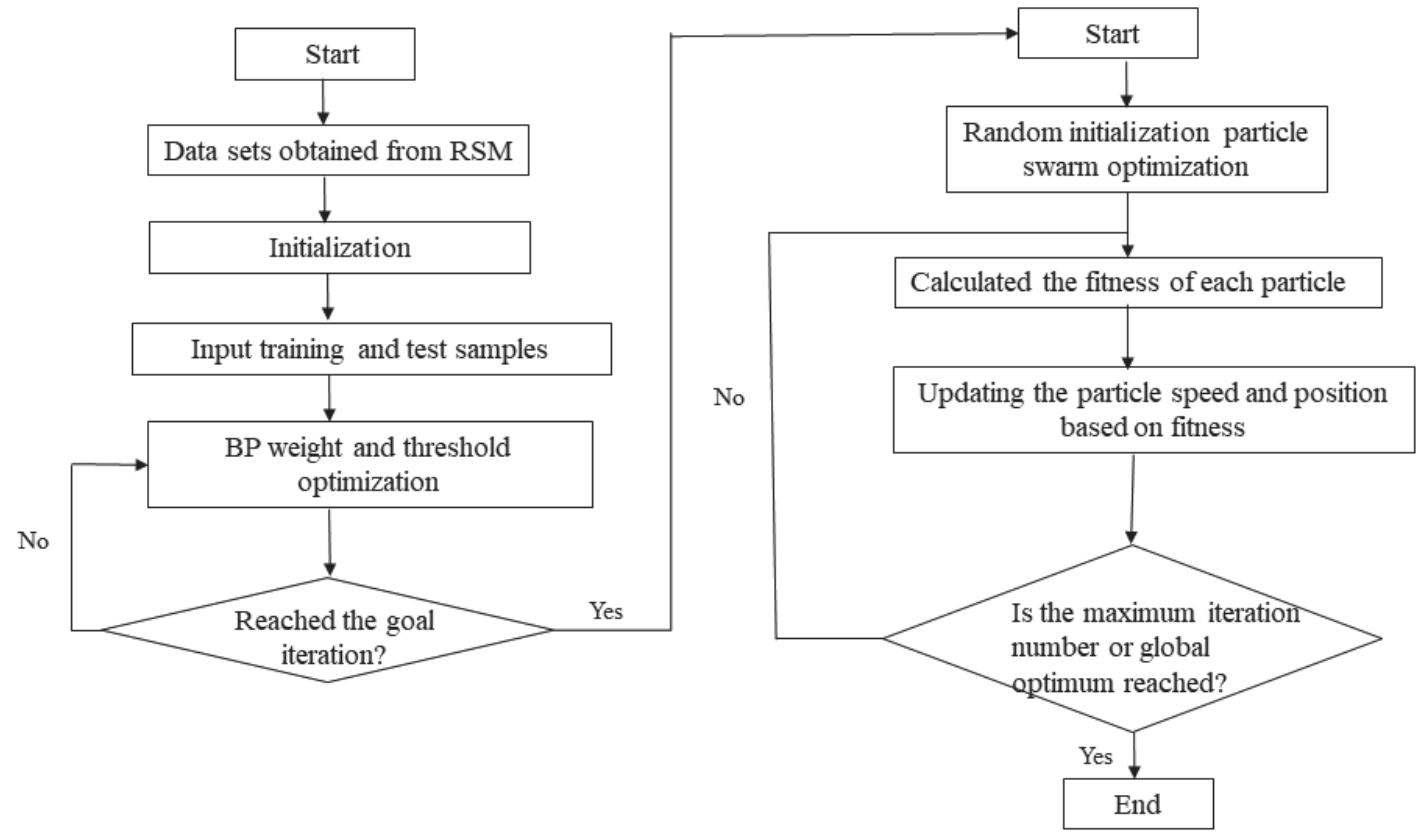

Fig. 2. Operation diagram of ANN-PSO. 
Table 4. The removal efficiency of biological carbon prepared by pomelo peel at different cracking temperatures.

\begin{tabular}{|c|c|c|c|c|}
\hline Temperature $\left({ }^{\circ} \mathrm{C}\right)$ & Initial MB concentration $(\mathrm{g} / \mathrm{L})$ & $\mathrm{C}_{\mathrm{e}}(\mathrm{mg} / \mathrm{L})$ & $q_{\mathrm{e}}(\mathrm{mg} / \mathrm{g})$ & Removal efficiency (\%) \\
\hline 450 & \multirow{3}{*}{10} & 0.1535 & 9.8465 & $98 \%$ \\
\hline 500 & & 0.0828 & 9.9172 & $99 \%$ \\
\hline 550 & & 3.7852 & 6.2148 & $62 \%$ \\
\hline 450 & \multirow{3}{*}{15} & 0.2046 & 14.7954 & $99 \%$ \\
\hline 500 & & 0.0946 & 14.9054 & $99 \%$ \\
\hline 550 & & 6.3922 & 8.6078 & $57 \%$ \\
\hline
\end{tabular}

\section{Characterization of Biochar Prepared by Pomelo} Peel at Three Different Temperatures

Fig. 3 exhibits the SEM spectrum of biochar prepared by pomelo peel and calcined at $450^{\circ} \mathrm{C}, 500^{\circ} \mathrm{C}$ and $550^{\circ} \mathrm{C}$ for $3 \mathrm{~h}$ in vacuum tube furnace. The gap junction on the surface of biochar is mainly related to the decomposition of cellulose and hemicellulose in the material. A large amount of volatile components will be precipitated from the inner part of the prepared biochar, and thus the porous structure will be loose [27]. The bulk structure is increased with the enhancement of calcination temperature, rendering that the surface becomes rougher, which may be due to the pore collapse caused by the sample preparation and drying process [28]. These pores play an important role in the adsorption and surface area of biochar.

Fig. 4 shows the surface functional group structure of biochar prepared by pomelo peel at the three calcination temperature by FT-IR. With the increase of calcination temperature, the $\mathrm{O}-\mathrm{H}$ of phenolic hydroxyl stretching vibration $\left(3404 \mathrm{~cm}^{-1}\right)$ of modified pomelo peel based biochar did not change significantly, indicating the existence of strong $\mathrm{O}-\mathrm{H}$ or adsorbed water. The characteristic peak of $\mathrm{C}=\mathrm{O}$ stretching vibration is found at $1600-1700 \mathrm{~cm}^{-1}$, which is decreased with the increase of calcination temperature. This may be due to the deoxidation and carbonization reaction when
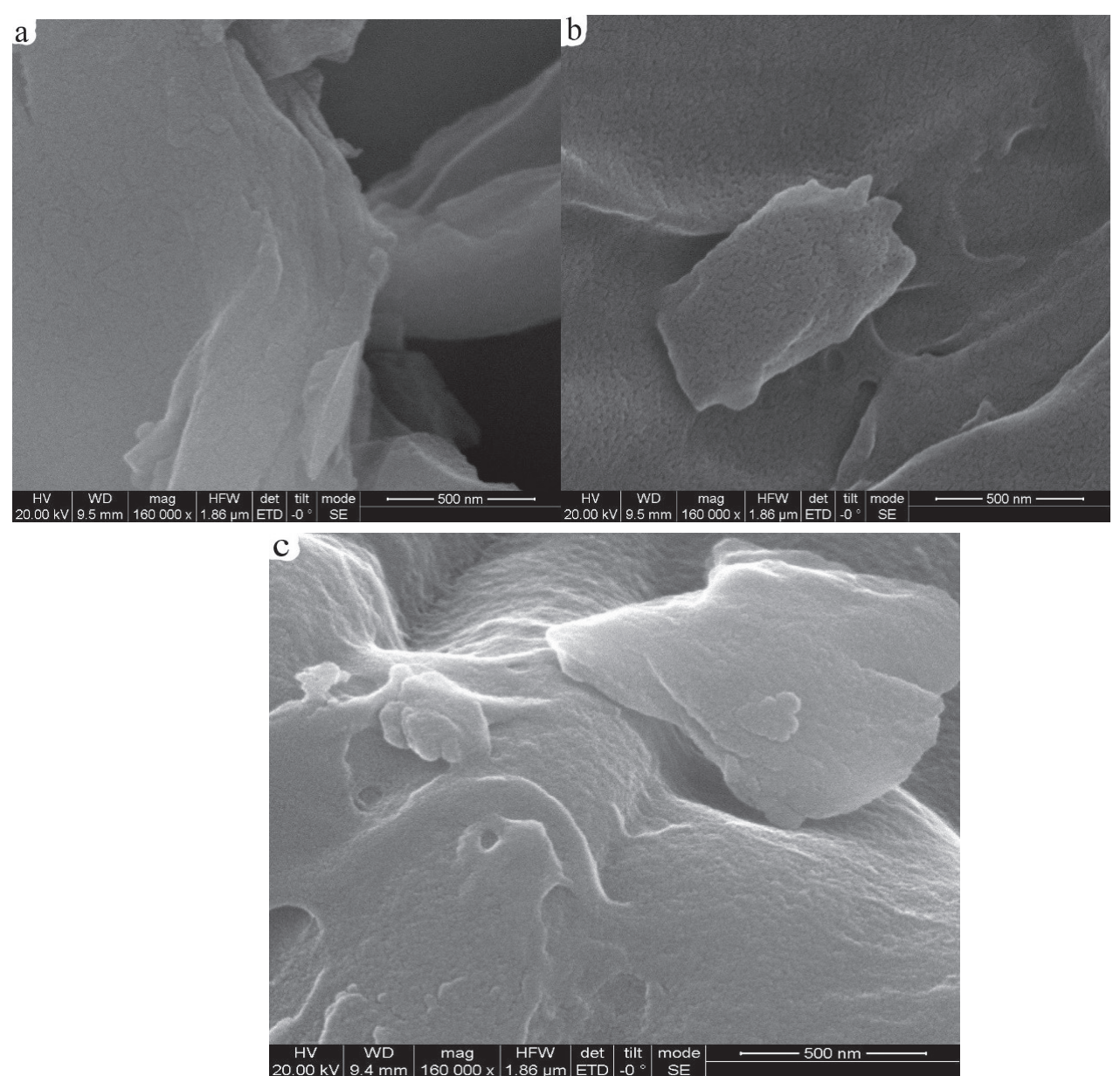

Fig. 3. SEM of biological carbon prepared by pomelo peel calcined at $\left.\left.450^{\circ} \mathrm{C} \mathrm{a}\right), 500^{\circ} \mathrm{C} \mathrm{b}\right)$ and $\left.550^{\circ} \mathrm{C} \mathrm{c}\right)(\times 160000$ times $)$. 


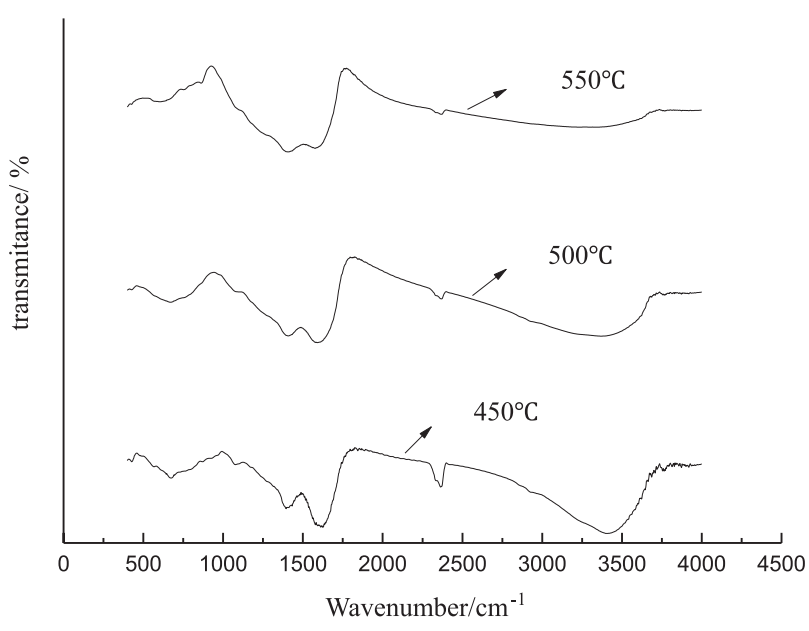

Fig. 4. FI-IR characterization of biological carbon prepared by pomelo peel calcined at $450^{\circ} \mathrm{C}, 500^{\circ} \mathrm{C}$ and $550^{\circ} \mathrm{C}$.

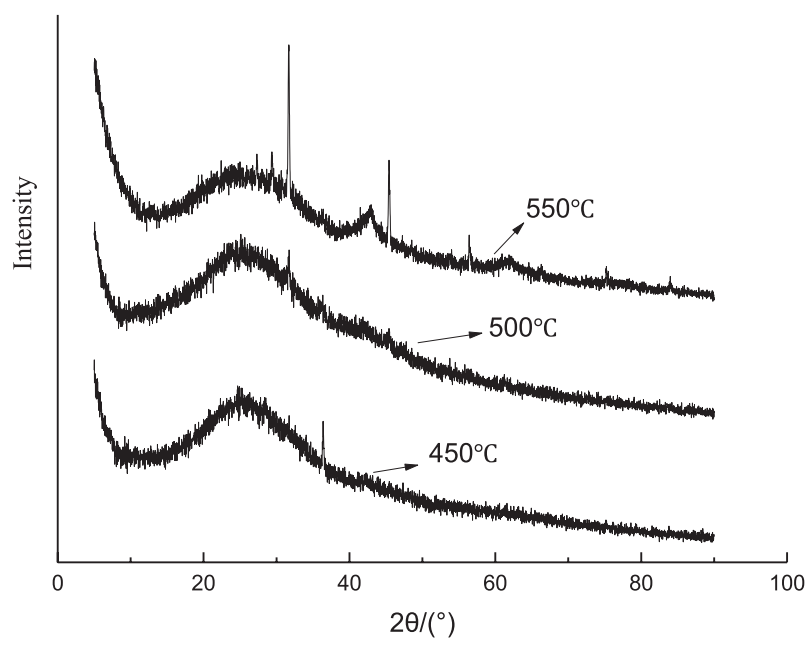

Fig. 5. XRD characterization of biological carbon prepared by pomelo peel calcined at $450^{\circ} \mathrm{C}$ a), $500^{\circ} \mathrm{C} \mathrm{b}$ ) and $550^{\circ} \mathrm{C} \mathrm{c}$ ).

the pyrolysis temperature rises from $450^{\circ} \mathrm{C}$ to $550^{\circ} \mathrm{C}$, however, the process is no longer the main pyrolysis reaction [29]. At $1450-1500 \mathrm{~cm}^{-1}$, the characteristic peak of $\mathrm{C}=\mathrm{C}$ (benzene ring) skeleton vibration weakens with the increase of calcination temperature, which may be due to the splitting decomposition of benzene ring structure with the increase of calcination temperature. There is an out-of-plane bending peak of aromatic C-H at $850-900 \mathrm{~cm}^{-1}$, which may be due to dehydrogenation and aromatic polymerization. There are characteristic peaks of C-O-C stretching vibration at 210-1 $030 \mathrm{~cm}^{-1}$. FT-IR characterization of modified pomelo peel based biochar showed that the material may be composed of lignin, cellulose and hemicellulose with a large number of active functional groups. These active functional groups can interact with pollutants to remove pollutants from the solution.

Fig. 5 demonstrates XRD used to analyze the modified pomelo peel based biochar at different temperatures. There was an obvious widely peak at $2 \theta=24.67^{\circ}$ and $45.42^{\circ}$, respectively, corresponding to the characteristic peaks of planes (002) and (101) of local ordered carbon layer structure, and indicating the existence of aromatic carbon structure [30]. The intensity of the broad peak at $45.42^{\circ}$ increases with the improving temperature, which is due to the enhancement of structure composition of aromatic carbon. The characteristic peak of $\mathrm{CaCO}_{3}$ appears at $2 \theta=29.5^{\circ}$ when the pomelo peel based biochar is calcined under $550^{\circ} \mathrm{C}$.

Table 5 exhibits the lesser specific surface area of modified pomelo peel based biochar, which may be due to the carbonization process used in this study. Because nitrogen is only supplied before the improving temperature of the system to ensure the anoxic environment, the continuous external gas flow is not carried out in time during the carbonization process, resulting in the attachment of other products onto the surface of modified pomelo peel based biochar [31]. In addition, with the increase of temperature, the specific surface area and total pore volume of modified pomelo peel based biochar are increased, and the average pore size is decreased, indicating that the increase of temperature makes the pore size of modified pomelo peel based biochar changed from small and large distribution into small and dense structure. This may be caused by the accumulation and escape of volatile gas during the calcination process, which is consistent with the results of SEM characterization. The specific surface areas of the modified pomelo peel based biochar of three different temperature are 2.511, 3.353 and $4.344 \mathrm{~m}^{2} / \mathrm{g}$, respectively. The effect of temperature on the average pore size of the three kinds of biochars is basically the same, and the modified pomelo peel based biochar is mainly mesoporous (2-50 nm) (Fig. 6).

Thermogravimetric analysis can find the composition changes of modified pomelo peel based biochar with mass loss, and hence to explore the thermal stability of the biochar. Fig. 7 shows that the first weight loss plateau of modified pomelo peel based biochar calcined at the three temperatures is approximately 100 $200^{\circ} \mathrm{C}$. In this process, it is mainly the loss of water and some low molecular weight alkanes. Because the water content of modified pomelo peel based biochar and air dried pomelo peel biomass is less, the thermal weight loss curve at $100-200^{\circ} \mathrm{C}$ is relatively smooth, thereby, the mass loss of several biochar and their original samples is basically less than $10 \%$ [32]. The second platform of weight loss of modified pomelo peel based biochar appears in the temperature range of 200$400^{\circ} \mathrm{C}$, and the mass loss rate is approximately $20 \%$. In biochar, hemicellulose is the most easily pyrolyzed, cellulose is the second, and lignin is the most difficult. Therefore, the second platform is mainly due to the massive decomposition of cellulose and hemicellulose. The third stage of weight loss of modified pomelo peel based biochar is the decomposition of lignin above $400-600^{\circ} \mathrm{C}$, which is slow and accompanied by the 

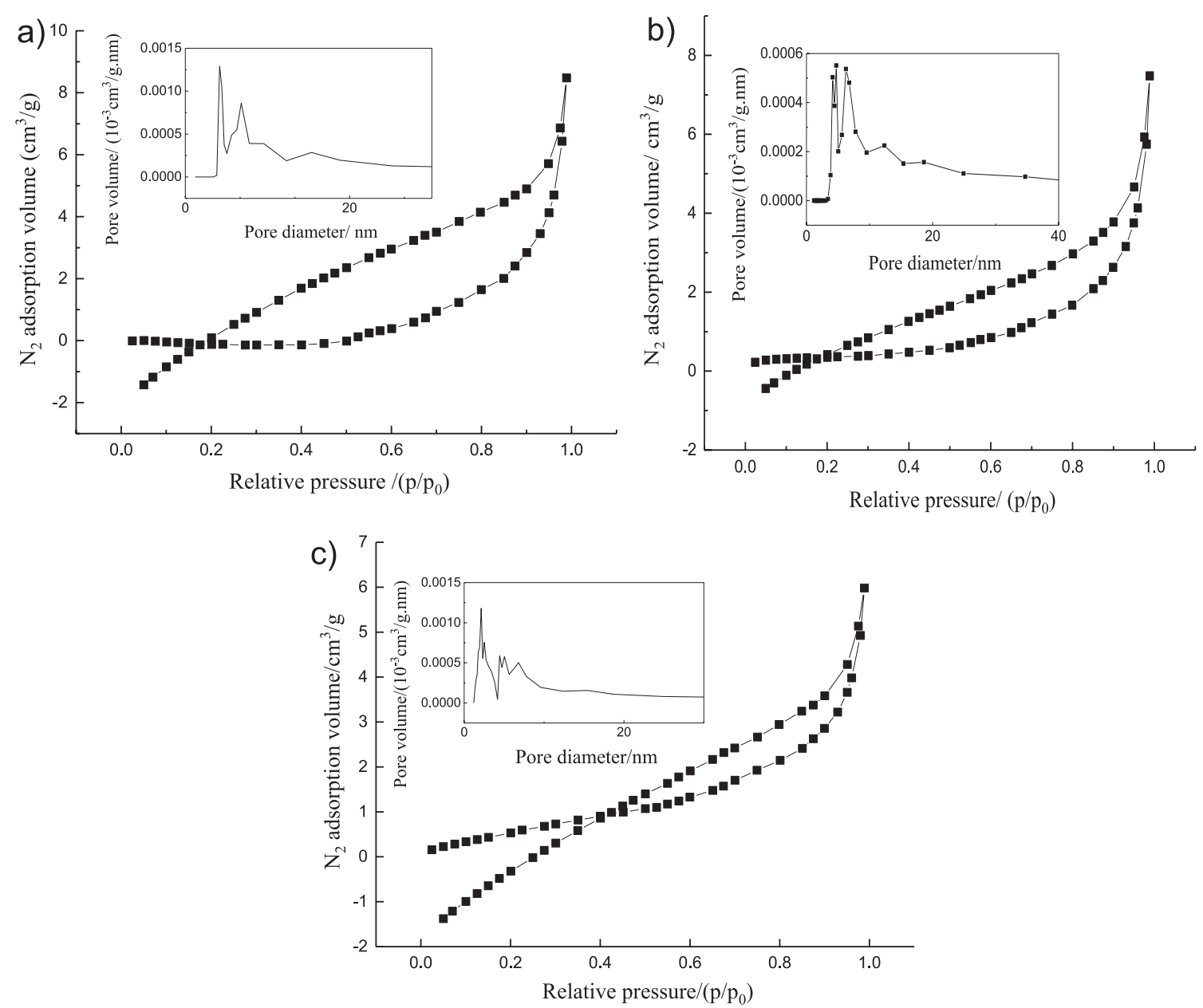

Fig. 6. $\mathrm{N}_{2}$ adsorption characterization of biological carbon prepared by pomelo peel calcined at $\left.\left.450^{\circ} \mathrm{C} \mathrm{a}\right), 500^{\circ} \mathrm{C} \mathrm{b}\right)$ and $550^{\circ} \mathrm{C} \mathrm{c}$ ).

cracking of aromatic nucleus, and the mass loss rate is about $50 \%$. The last stage is from $600^{\circ} \mathrm{C}$ to the end of the experiment, which is a process of slow decomposition of residual substances.

\section{Optimization of MB Removal by Modified Pomelo Peel Based Biochar Using RSM}

Based on the single factor experiment and design of RSM, the contact time, temperature, initial methylene blue concentration and initial $\mathrm{pH}$ of $\mathrm{MB}$ adsorption by modified pomelo peel based biochar was set at 60-80 $\mathrm{min}, \quad 20-40^{\circ} \mathrm{C}, \quad 100-200 \mathrm{mg} / \mathrm{L}$ and $6-8$, respectively (Table 6). By modeling the experimental data, the $\mathrm{R}^{2}$ value of the established model was 0.9948 , and the sum of squares for the developed model reached at 781.05. In addition, the significant level $(\mathrm{p}<0.0001)$ and the non-significant term of the model $(p=0.8495)$ showed that the established model was available and effective (Table 7). The quadratic polynomial of the model is as follows:

$$
\begin{gathered}
f=76.18+0.40 \mathrm{~A}+1.13 \mathrm{~B}-2.13 \mathrm{C}+0.016 \mathrm{D}- \\
0.93 \mathrm{AB}+6.58 \mathrm{AC}-6.31 \mathrm{AD}+4.88 \mathrm{BC}-7.30 \mathrm{BD}- \\
3.91 \mathrm{CD}+0.40 \mathrm{~A}^{2}-0.46 \mathrm{~B}^{2}-0.30 \mathrm{C}^{2}+0.69 \mathrm{D}^{2}
\end{gathered}
$$

Through the analysis of the established model, it can be concluded that the order of influencing factors of $\mathrm{MB}$ adsorption by modified pomelo peel based biochar are initial $\mathrm{MB}$ concentration $>$ temperature $>$ con tact time $>$ initial $\mathrm{pH}$ according to the $\mathrm{F}$ value of each factor. Wang et al. [33] reported that attapulgite was

Table 5. Pore size parameters of biological carbon prepared by pomelo peel at different calcination temperatures.

\begin{tabular}{|c|c|c|c|}
\hline Calcination of the different pomelo peel biochar & Specific surface area & Total pore volume & Average pore diameter \\
\hline $450^{\circ} \mathrm{C}$ & 2.511 & 0.012 & 4.73 \\
\hline $500^{\circ} \mathrm{C}$ & 3.353 & 0.015 & 4.181 \\
\hline $550^{\circ} \mathrm{C}$ & 4.344 & 0.01 & 2.126 \\
\hline
\end{tabular}



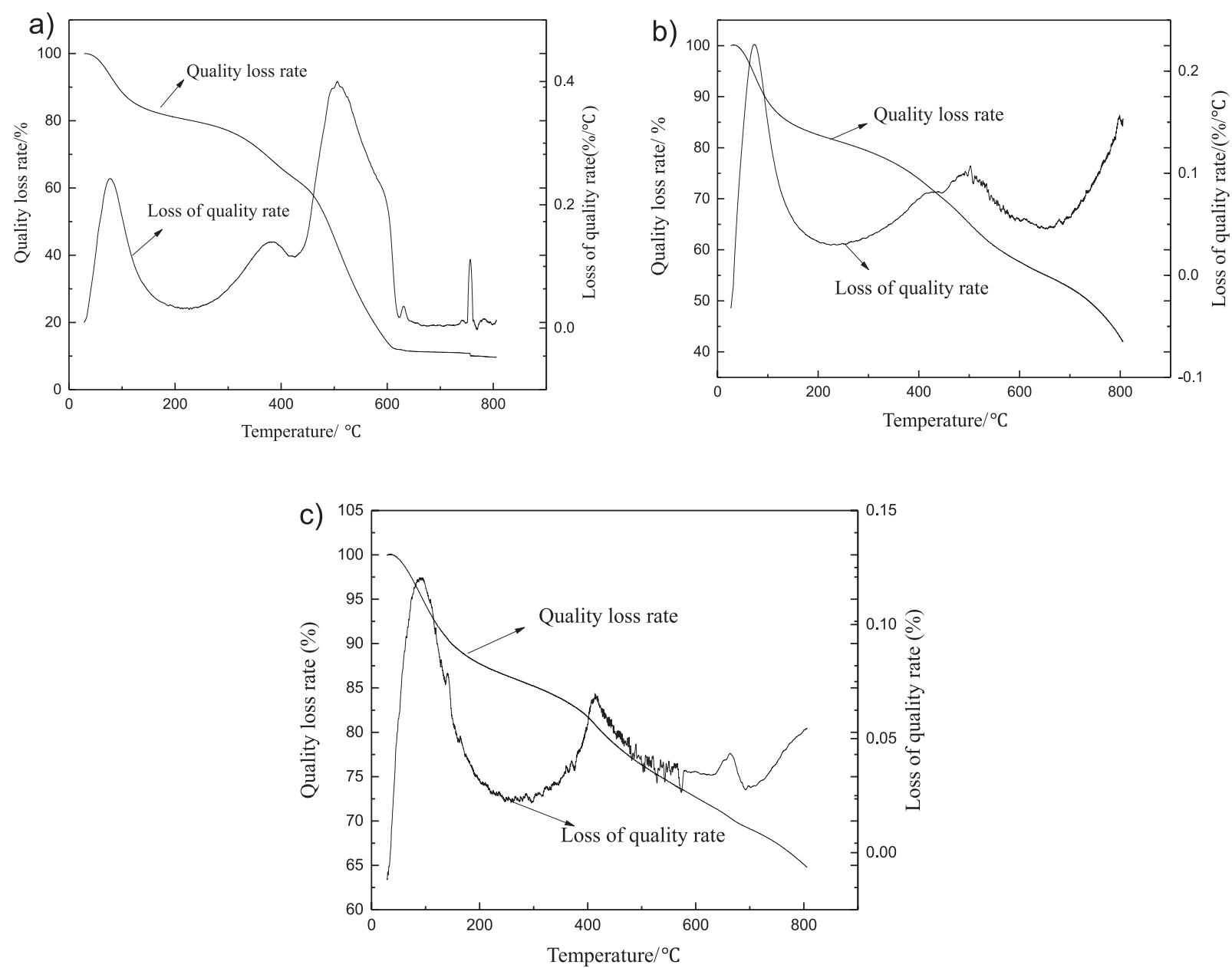

Fig. 7. TGA characterization of biological carbon prepared by pomelo peel calcined at $450^{\circ} \mathrm{C} \mathrm{a}$ ), $500^{\circ} \mathrm{C} \mathrm{b}$ ) and $550^{\circ} \mathrm{C} \mathrm{c}$ ).

used as adsorption material to study the adsorption of methylene blue in simulated water samples. RSM was used to optimize the adsorption process and the order of influence factors on decolorization rate was adsorbent dosage $>$ initial concentration $>$ temperature $>$ initial $\mathrm{pH}$. Wu et al. [34] described the self-made magnetic $\mathrm{Fe}_{3} \mathrm{O}_{4} / \mathrm{GO}$ nanocomposites used to remove $\mathrm{Cd}$ (II) from aqueous solution. RSM analysis of variance showed that the effect of four factors on the removal of Cd (II) from aqueous solution was as follows: Initial Cd (II) concen tration $>$ temperature $>$ contact time $>\mathrm{pH}$ value. Xie et al. [24] exhibited the attapulgite modified by Keggin ion composites were successfully synthesized to remove $\mathrm{Cu}$ (II) in aqueous system and RSM was used to optimize the conditions of removal process. The order of influence of four factors on $\mathrm{Cu}$ (II) removal was initial $\mathrm{pH}>$ initial $\mathrm{Cu}$ (II) concentration $>$ reaction time $>$ temperature. The results of this study are inconsistent with previous studies, which may be related to the selection of removal objects and experimental conditions

The calibration coefficient $\left(\mathrm{R}^{2}\right)$ of the model is 0.9895 , and its signal-to-noise ratio is 45.24 . Generally, the value greater than 4 meets the requirements of the model. The results showed that $\mathrm{R}^{2}=0.9895-0.9799=$
0.0096 (less than 0.2 ) and the coefficient of variation (\%) was $0.91 \%$ (far less than $10 \%$ ), indicating that the model had high fitting accuracy and small error. The above results suggest that the developed model could be used to optimize the adsorption conditions of MB by modified pomelo peel based biochar. Through the optimization of the model, the maximum efficiency of MB removal using modified pomelo peel based biochar from aqueous solutions was $84.24 \%$ under the contact time was $64.82 \mathrm{~min}$, initial MB concentration was $118.2 \mathrm{mg} / \mathrm{L}$, temperature was $31.01^{\circ} \mathrm{C}$ and initial $\mathrm{pH}$ was 7.88. Under these experimental conditions, the removal efficiency of verification experiment was $81.19 \%$, and the absolute error was $3.05 \%$. Khosravi and Arabi [35] reported iron zero-valent composites were used to remove MB dye in water solution with the aid of RSM. The results implied that the optimal parameters for $\mathrm{MB}$ removal were the dose of iron zero-valent composites $=0.1-0.9 \mathrm{~g} / \mathrm{L}, \mathrm{pH}=3-11$, contact time $=20-100 \mathrm{~s}$ and initial MB dye concentration $=10-50 \mathrm{mg} / \mathrm{L}$, respectively. Under these optimal values of process parameters, the MB dye removal rate of $92.87 \%$ was observed, nearing the validation value $(92.21 \%)$ in batch experiment. Sapawe et al. [36] elaborated that microwave prepared zeolite $\mathrm{NaA}$ was 
Table 6. Experimental design matrix and results.

\begin{tabular}{|c|c|c|c|c|c|}
\hline Codes & Contact time ( $\min )$ & Temperature $\left({ }^{\circ} \mathrm{C}\right)$ & Initial $\mathrm{MB}$ concentration $(\mathrm{mg} / \mathrm{L})$ & Initial $\mathrm{pH}$ & Removal efficiency (\%) \\
\hline 1 & 60 & 30 & 150 & 8 & 83.13 \\
\hline 2 & 70 & 30 & 100 & 8 & 82.79 \\
\hline 3 & 70 & 30 & 200 & 6 & 78.54 \\
\hline 4 & 70 & 40 & 150 & 8 & 70.27 \\
\hline 5 & 70 & 20 & 150 & 8 & 82.78 \\
\hline 6 & 60 & 40 & 150 & 7 & 76.86 \\
\hline 7 & 70 & 40 & 150 & 6 & 84.68 \\
\hline 8 & 70 & 30 & 150 & 7 & 76.63 \\
\hline 9 & 70 & 20 & 100 & 7 & 81.08 \\
\hline 10 & 70 & 40 & 200 & 7 & 79.12 \\
\hline 11 & 70 & 30 & 100 & 6 & 75.2 \\
\hline 12 & 70 & 30 & 150 & 7 & 76.64 \\
\hline 13 & 70 & 30 & 150 & 7 & 76.02 \\
\hline 14 & 70 & 20 & 150 & 6 & 67.99 \\
\hline 15 & 70 & 40 & 100 & 7 & 73.44 \\
\hline 16 & 80 & 20 & 150 & 7 & 75.95 \\
\hline 17 & 70 & 30 & 200 & 8 & 70.48 \\
\hline 18 & 70 & 30 & 150 & 7 & 75.04 \\
\hline 19 & 60 & 30 & 150 & 6 & 70.37 \\
\hline 20 & 70 & 20 & 200 & 7 & 67.24 \\
\hline 21 & 60 & 30 & 200 & 7 & 67.57 \\
\hline 22 & 60 & 30 & 100 & 7 & 84.93 \\
\hline 23 & 80 & 30 & 200 & 7 & 80.83 \\
\hline 24 & 80 & 30 & 150 & 8 & 71.14 \\
\hline 25 & 70 & 30 & 150 & 7 & 76.58 \\
\hline 26 & 80 & 30 & 100 & 7 & 71.87 \\
\hline 27 & 80 & 30 & 150 & 6 & 83.62 \\
\hline 28 & 60 & 20 & 150 & 7 & 74.1 \\
\hline 29 & 80 & 40 & 150 & 7 & 78.34 \\
\hline
\end{tabular}

utilized to remove MB from simulated wastewater. These materials of $1.0 \mathrm{~g} / \mathrm{L}$ exhibited the optimum dosage for adsorption of $120 \mathrm{mg} / \mathrm{L} \mathrm{MB}$, with predicted adsorption uptake of $53.5 \mathrm{mg} / \mathrm{g}$, at $\mathrm{pH} 7$ within $1 \mathrm{~h}$ of contact time at room temperature, approximating the environmental value $(50.7 \mathrm{mg} / \mathrm{g})$. Sadhukhan et al. [37] revealed that RSM was used to the removal of MB from water using neem (Azadirachta indica) bark dust (NBD) as a bioadsorbent. The four impact factors, including initial concentration $=500-1000 \mathrm{mg} / \mathrm{L})$, bioadsorbent dose $=0.20-1.50 \mathrm{~g} /(100 \mathrm{~mL}), \mathrm{pH}=5-12$, and stirring rate $=250-650 \mathrm{rpm}$, was investigated. The results exhibited a well fit of the experimental values to the second-order polynomial model with coefficient of determination $\left(\mathrm{R}^{2}\right)$ value of 0.9760 and model $\mathrm{F}$ value of 40.68 .

Optimization of MB Removal by Modified Pomelo Peel Based Biochar Using ANN-PSO

BP neural network includes input layer, hidden layer and output layer. The model will be over fitted if the number of neurons in hidden layer is large. When the number of neurons is too small, the model fitting will be insufficient. Both of them will reduce the generalization ability of the model, obtaining the inaccurately predicted results. Therefore, according to the lowest MSE value, 
Table 7. ANOVA for response surface quadratic model.

\begin{tabular}{|c|c|c|c|c|c|c|}
\hline Source & Sum of squares & Degree of freedom & Mean square & F value & $P$ value & \\
\hline Model & 781.05 & 14 & 55.79 & 189.53 & $<0.0001$ & Significant \\
\hline Contact time & 1.91 & 1 & 1.91 & 6.5 & 0.0232 & \\
\hline Initial MB concentration & 15.35 & 1 & 15.35 & 52.13 & $<0.0001$ & \\
\hline Temperature & 54.32 & 1 & 54.32 & 184.52 & $<0.0001$ & \\
\hline Initial $\mathrm{pH}$ & 0.0030 & 1 & 0.003008 & 0.01 & 0.9209 & \\
\hline $\begin{array}{c}\text { Contact time - Initial MB } \\
\text { concentration }\end{array}$ & 0.034 & 1 & 0.034 & 0.12 & 0.7382 & \\
\hline Contact time -Temperature & 173.19 & 1 & 173.19 & 588.35 & $<0.0001$ & \\
\hline Contact time -Initial $\mathrm{pH}$ & 159.26 & 1 & 159.26 & 541.06 & $<0.0001$ & \\
\hline Initial MB concentration - Temperature & 95.26 & 1 & 95.26 & 323.61 & $<0.0001$ & \\
\hline Initial MB concentration - Initial $\mathrm{pH}$ & 213.16 & 1 & 213.16 & 724.15 & $<0.0001$ & \\
\hline Temperature - Initial $\mathrm{pH}$ & 61.23 & 1 & 61.23 & 208.01 & $<0.0001$ & \\
\hline Contact time $^{2}$ & 1.04 & 1 & 1.04 & 3.54 & 0.0807 & \\
\hline Initial MB concentration $^{2}$ & 1.35 & 1 & 1.35 & 4.59 & 0.0502 & \\
\hline Temperature $^{2}$ & 0.59 & 1 & 0.59 & 2 & 0.1789 & \\
\hline Initial $\mathrm{pH}^{2}$ & 3.05 & 1 & 3.05 & 10.37 & 0.0062 & \\
\hline Residual & 4.12 & 14 & 0.29 & & & \\
\hline Lack of Fit & 2.22 & 10 & 0.22 & 0.47 & 0.8495 & Not significant \\
\hline Pure Error & 1.9 & 4 & 0.47 & & & \\
\hline Cor Total & 785.17 & 28 & & & & \\
\hline
\end{tabular}

$\mathrm{R}^{2}=0.9948 ;$ Adj. $\mathrm{R}^{2}$ value $=0.9895 ;$ Pre. $\mathrm{R}^{2}$ value $=0.9799 ;$ Adequate precision $=45.238 ;$ Coefficient of variation $=0.91 \%$

PSO is used to optimize the number of neurons in the hidden layer of BP network. In this study, 4 neurons are used in the hidden layer (Fig. 8). Referred to the previous published literature [24], the parameters of BP neural network are set as follows: epoch $=2000$, learning rate $=0.1$, goal value of $\mathrm{MSE}=1 \times 10^{-5}$ and momentum factor $=0.9$. Because the model is a "black box model", the specific equation cannot be obtained, however, the $\mathrm{R}^{2}$ value of the established model is 0.9985 , which indicates that the experimental value of the model is in good agreement with the predicted value (Fig. 9).

ANN-PSO was used to optimize the conditions of $\mathrm{MB}$ removal by the modified pomelo peel based biochar and can obtain the global optimal solution (Fig. 10). Referred to the previous published literature [24], the parameters of PSO are set as follows: the minimum inertia weight is 0.3 ; the maximum inertia weight is $0.9 ; \mathrm{C} 1$ and $\mathrm{C} 2$ are 2; the group length is 20 and the maximum iterations number is 500 . The maximum removal efficiency of $\mathrm{MB}$ was $89.72 \%$ by BP-PSO, corresponding that experimental conditions were as follows: temperature $=34.63^{\circ} \mathrm{C}$, reaction time $=80.00 \mathrm{~min}$, initial $\mathrm{MB}$ concentration $=169.7 \mathrm{mg} / \mathrm{L}$ and initial $\mathrm{pH}=7$. Under these conditions, the actual removal efficiency is $87.96 \%$, and the absolute error is $1.76 \%$. The optimization results of RSM and PSO are not consistent, which may be due to their different optimization mechanism. RSM uses multiple quadratic regression equation to fit the functional relationship between the factors and the response value. Through the analysis of the regression equation to seek the optimal process parameters, however, it is likely to fall into the local optimum. PSO algorithm can complete the training of connection weights, structure design, learning rule adjustment, feature selection, initialization of connection weights and rule extraction in artificial neural network [38]. The speed is not as good as gradient descent optimization, which requires large computing resources. Its advantages are simple, easy to implement, no gradient information, few parameters, especially its natural real coding characteristics, especially suitable for dealing with real optimization problems [39]. Liu et al. [40] realize the high-density culture of Saccharomyces boulardii, the high-density fermentation medium and fermentation process were optimized. Plackett Burman test was used to screen the significant factors in the medium, and central composite design was carried out. The relationship model between the yield of Saccharomyces boulardii and 
the medium was established by ANN and RSM, and genetic algorithm is used for global optimization. The results showed that ANN model has better data fitting ability and prediction ability, and was more suitable for dealing with complex nonlinear problems. Li et al. [41] optimized the preparation conditions of garlic flavoring powder, the effects of drying temperature, slice thickness and drying time on the flavor characteristics of garlic flavoring powder were studied. High quality garlic flavoring powder was prepared by hot air drying method. Box Behnken response surface method was used to design the garlic flavoring powder with sensory score as response value, and back propagation artificial neural network and genetic algorithm were used, The results showed that the optimal parameters were as follows: drying time $5.9 \mathrm{~h}$, drying temperature $61^{\circ} \mathrm{C}$, slice thickness $2.7 \mathrm{~mm}$. Under these conditions, the experimental value of garlic powder sensory score was 18.70 , and the predicted value of GA-BP neural network model was 18.5622 , The relative error between the experimental value and the predicted value is $0.74 \%$, and the fitting degree of the model is very good, which indicates that the application of GA-BP neural network to optimize the preparation conditions of garlic flavoring powder is reasonable and feasible.

\section{Adsorption Mechanism}

\section{Kinetic Studies}

In this experiment, the pseudo-first-order kinetic and pseudo-second-order kinetic models were used to describe the kinetic characteristics of MB adsorption on modified pomelo peel based biochar. The equation is as follows [42, 43]:

$$
\begin{gathered}
\ln \left(q_{e}-q_{t}\right)=\ln q_{e}-k_{1} t \\
\frac{t}{q_{t}}=\frac{1}{k_{2} q_{e}{ }^{2}}+\frac{t}{q_{e}}
\end{gathered}
$$

...where $q_{\mathrm{e}}$ and $q_{\mathrm{t}}(\mathrm{mg} / \mathrm{g})$ represents the adsorption capacity of $\mathrm{MB}$ adsorbed onto modified pomelo peel based biochar at equilibrium and certain time, respectively. $K_{1}$ is the first-order kinetic rate constant $\left(\mathrm{min}^{-1}\right) . \mathrm{K}_{2}$ is the rate constant of the pseudo-secondorder kinetics $(\mathrm{g} /(\mathrm{mg} \cdot \mathrm{min}))$.

The adsorption data of modified pomelo peel based biochar with different concentrations of $\mathrm{MB}$ were fitted with the pseudo-first-order and pseudo-second-order models (Table 8). Fig. 11 demonstrates that the pseudosecond-order kinetic equation can better describe the behavior of $\mathrm{MB}$ adsorption onto modified pomelo peel based biochar in aqueous solution system. This indicates that the adsorption process of MB by biochar is more in line with the pseudo-second-order kinetic model, and the adsorption rate is mainly controlled by chemical adsorption.

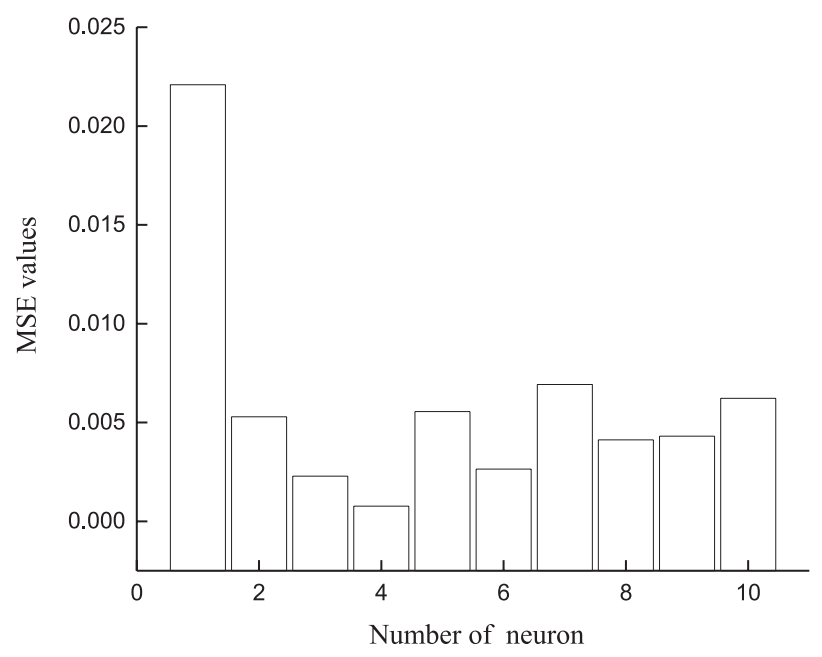

Fig. 8. Relationship between MSE and number of hidden layer neuron.

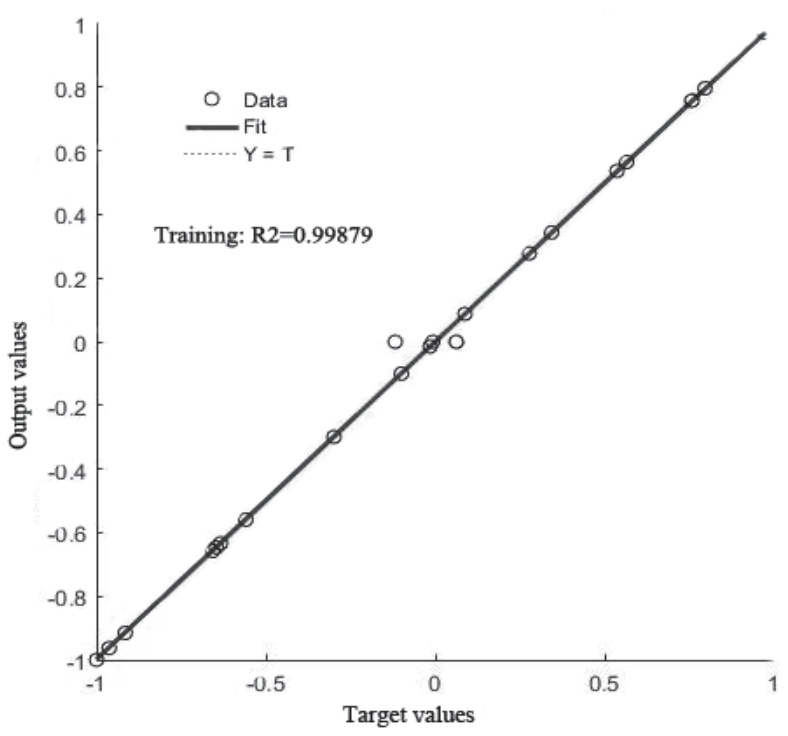

Fig. 9. The relationship between MSE and sample training.

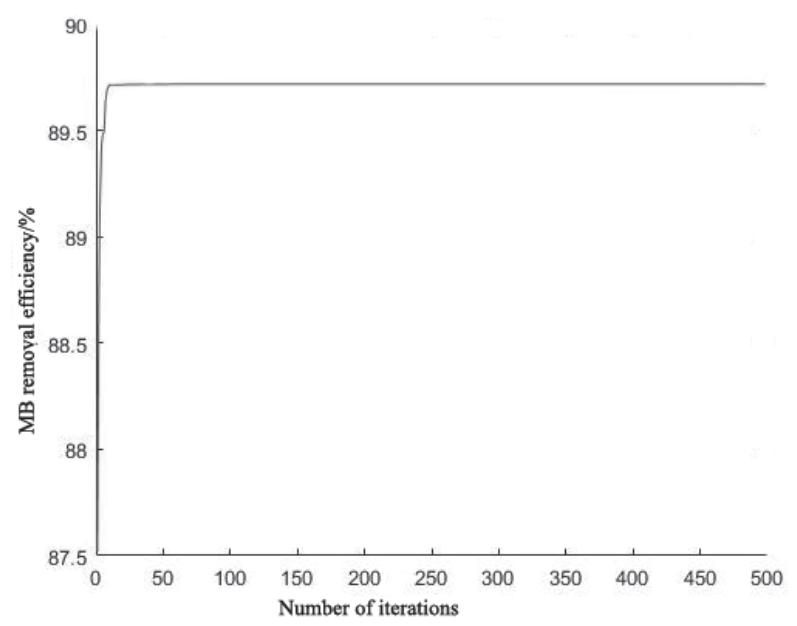

Fig. 10. BP-PSO optimization results. 
Table 8. Kinetics fitting parameters of methylene blue adsorption onto biological carbon prepared by pomelo peel.

\begin{tabular}{|c|c|c|c|c|c|}
\hline \multicolumn{3}{|c|}{ Pseudo-first-order kinetic } & \multicolumn{3}{c|}{ Pseudo-second-order kinetic } \\
\hline$k_{1}$ & $q_{e}(\mathrm{mg} / \mathrm{g})$ & $R^{2}$ & $k_{2}$ & $q_{e}(\mathrm{mg} / \mathrm{g})$ & $R^{2}$ \\
\hline 0.0629 & 72.4306 & 0.8400 & $6.31 \times 10^{-4}$ & 113.6364 & 0.9952 \\
\hline
\end{tabular}

\section{Isothermal Adsorption Study}

The adsorption of MB by modified pomelo peel based biochar is a dynamic equilibrium process. In order to explore the adsorption behavior of these materials, Langmuir and Freundlich isothermal adsorption models were used in this experiment, and their equation are as follows $[44,45]$ :

$$
\begin{gathered}
\frac{C_{e}}{q_{e}}=\frac{1}{K_{L} q_{\max }}+\frac{C_{e}}{q_{\max }} \\
\ln q_{e}=\ln K_{F}+\frac{1}{n} \ln C_{e}
\end{gathered}
$$

...where $q_{\mathrm{e}}$ is the equilibrium adsorption capacity of $\mathrm{MB}$ onto modified pomelo peel based biochar (mg/g). $\mathrm{Ce}$ represents the equilibrium concentration of MB $(\mathrm{mg} / \mathrm{L}) . q_{\max }$ is the maximum adsorption capacity of the adsorbent monolayer, $\mathrm{K}_{\mathrm{L}}$ is the Langmuir adsorption constant $(\mathrm{L} / \mathrm{mg}) . \mathrm{K}_{\mathrm{F}}((\mathrm{mg} / \mathrm{g}) /(\mathrm{mg} / \mathrm{L}))$ and $1 / n$ are Freundlich constants, which is the binding force of adsorbent to adsorbate.

Fig. 12 exhibits the adsorption capacity of modified pomelo peel based biochar to MB increases with the increase of initial MB concentration. The adsorption capacity of the biochar dramatically increases under the lower initial MB concentration. The adsorption capacity

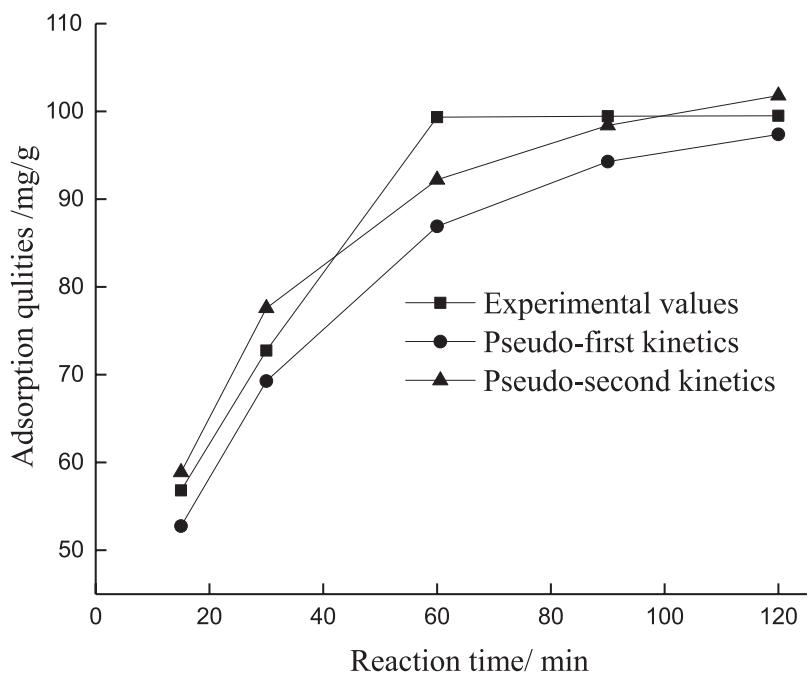

Fig. 11. Comparison of pseudo-first-order and pseudo-secondorder kinetics (the biochar dosage $=0.5 \mathrm{~g}$; temperature $=25^{\circ} \mathrm{C}$; initial $\mathrm{MB}$ concentration $=100 \mathrm{mg} / \mathrm{L}$ and initial $\mathrm{pH}=7$ ). of the biochar increases slowly under the higher initial MB concentration. Table 9 shows that Langmuir model can describe well the adsorption characteristics of modified pomelo peel based biochar used for MB removal in comparison with Freundlich model since the former is of the higher $\mathrm{R}^{2}$ value. Langmuir model assumed that a large number of adsorption active centers form the solid surface. The adsorption capacity of modified pomelo peel based biochar will decrease if the surface adsorption active centers are all occupied by MB. When the equilibrium value was reached, MB distributed in monolayer on the surface of the biochar. Table 10 compares the arsenic adsorption capacity of the biochar with that of other adsorbents. It was exhibited that the MB adsorption capacity of modified pomelo peel based biochar was slightly different from those of many other adsorbents, however, it is still a rather promising alternative for MB removal.

\section{Thermodynamic Parameters}

The adsorption thermodynamics can provide key information to evaluate spontaneous or exothermic nature of a removal process with different temperatures. Their equations $[54,55]$ can be expressed as:

$$
\ln K_{T}=\frac{\Delta S^{0}}{R}-\frac{\Delta H^{0}}{R T}
$$

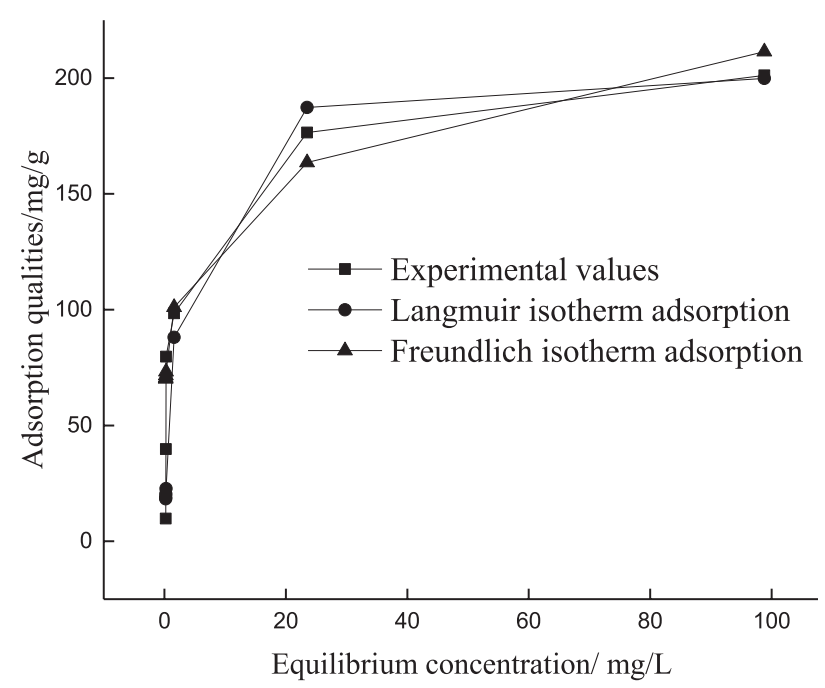

Fig. 12. Comparison of Langmuir and Freundlich adsorption isotherm model (the biochar dosage $=0.5 \mathrm{~g}$; temperature $=$ $25^{\circ} \mathrm{C}$; contact time $=60 \mathrm{~min}$ and initial $\mathrm{pH}=7$ ). 
Table 9. Adsorption isotherm fitting parameters for methylene blue adsorption onto biological carbon prepared by pomelo peel.

\begin{tabular}{|c|c|c|c|c|c|}
\hline \multicolumn{2}{|c|}{ Langmuir } & \multicolumn{3}{c|}{ Fredunlich } \\
\hline$q_{\mathrm{m}}(\mathrm{mg} / \mathrm{g})$ & $\mathrm{K}_{\mathrm{L}}$ & $R^{2}$ & $\mathrm{~K}_{\mathrm{F}}$ & $1 / n$ & $R^{2}$ \\
\hline 204 & 0.47 & 0.9986 & 92.76 & 0.1789 & 0.9762 \\
\hline
\end{tabular}

Table 10. Comparison of the different maximum adsorption capacities of MB.

\begin{tabular}{|c|c|c|c|}
\hline Materials & Maximum adsorption capacity $(\mathrm{mg} / \mathrm{g})$ & Activator & References \\
\hline Cotton stalk & 315.45 & $\mathrm{ZnCl}_{2}$ & {$[46]$} \\
\hline Waste tea & 554.30 & $\mathrm{CH}_{3} \mathrm{COOK}$ & {$[47]$} \\
\hline Oil palm fiber & 379.62 & $\mathrm{KOH}$ & {$[48]$} \\
\hline Orange peels & 243.66 & $\mathrm{~K}_{2} \mathrm{CO}_{3}$ & {$[49]$} \\
\hline Mangosteen peels & 277.45 & $\mathrm{~K}_{2} \mathrm{CO}_{3}$ & {$[49]$} \\
\hline Citrus pectin & 1155.2 & $\mathrm{ZnCl}_{2}$ & {$[50]$} \\
\hline Fish scales (Labeo rohita) & 184.40 & $\mathrm{NaOH}$ & {$[51]$} \\
\hline Coconut shell & 200.01 & $\mathrm{NaOH}^{2}$ & {$[52]$} \\
\hline Municipal solid wastes oxide & 21.83 & $\mathrm{MgCl}_{2}$ & In the present study \\
\hline
\end{tabular}

$$
\begin{gathered}
\Delta G^{0}=-R T \ln K_{T} \\
K_{T}=\frac{C_{0}}{C_{e}}
\end{gathered}
$$

...where $\Delta \mathrm{H}^{\circ}$ and $\Delta \mathrm{S}^{\circ}$ are the standard enthalpy change $\left(\mathrm{kJ}^{\circ} \mathrm{mol}^{-1} \cdot \mathrm{K}^{-1}\right)$ and the standard entropy change $\left(\mathrm{kJ} \cdot \mathrm{mol}^{-1} \cdot \mathrm{K}^{-1}\right)$, respectively, which can be obtained from the slope and intercept of a plot of $\ln \mathrm{K}_{0}$ against $1 / \mathrm{T}$, respectively; $\Delta \mathrm{G}^{\circ}$ is the standard free energy change $(\mathrm{kJ} / \mathrm{mol})$; $\mathrm{T}$ is the temperature $(\mathrm{K})$; $\mathrm{R}$ is gas constant $\left(8.314 \mathrm{~J} \cdot \mathrm{mol}^{-1} \cdot \mathrm{K}^{-1}\right)$.

The adsorption of MB by biochar is a spontaneous process because of $\Delta G^{0}<0$ (Table 11). $0<\Delta G^{0}<-20 \mathrm{~kJ} /$ mol is a physical adsorption process and $-80 \mathrm{~kJ} / \mathrm{mol}$ $<\Delta \mathrm{G}^{0}<-400 \mathrm{~kJ} / \mathrm{mol}$ is a chemical adsorption process, thereby, the adsorption process is a physical adsorption process (Table 11) [56]. In addition, $\Delta \mathrm{H}^{0}>0$ indicates

Table 11. The thermodynamic parameters for the adsorption of MB onto the biochar.

\begin{tabular}{|c|c|c|c|}
\hline $\begin{array}{c}\text { Temperature } \\
(\mathrm{K})\end{array}$ & $\begin{array}{c}\Delta \mathrm{G}_{0} \\
(\mathrm{~kJ} / \mathrm{mol})\end{array}$ & $\begin{array}{c}\Delta \mathrm{S}_{0} \\
(\mathrm{~J} \cdot \mathrm{mol}-1 \mathrm{~K}-1)\end{array}$ & $\begin{array}{c}\Delta \mathrm{H}_{0} \\
(\mathrm{~kJ} \cdot \mathrm{mol}-1)\end{array}$ \\
\hline 298 & -6.2475 & 31.6 & 3.196 \\
\hline 308 & -6.5148 & & \\
\hline 318 & -6.8134 & & \\
\hline 328 & -7.2012 & & \\
\hline
\end{tabular}

that the adsorption process is endothermic, and heating is conducive to the adsorption process. $\Delta \mathrm{S}^{0}>0$ exhibits that the adsorption process increases the disorder degree of solid-liquid interface, suggesting that the adsorption process is easy to occur. The forces of the adsorption process may be hydrogen bond, van der waals force and $\pi-\pi$ electron conjugation.

\section{Mechanism of MB Adsorbed onto the Modified Biochar and Regeneration of the Materials}

The adsorption of MB onto biochar was a relatively complex process. Based on the analysis of adsorption kinetics, the removal process includes physical acting and chemical bonding, viz. the external liquid film diffusion, surface adsorption and intra-particle diffusion processes [57] (Fig. 13). In addition, according to thermodynamic study and combing with the previous studies, the removal mechanism of $\mathrm{MB}$ onto the biochar involves electrostatic interaction, ion exchange, chemical action and physical behavior. Especially, FT-IR analysis have exhibited that the abundant $-\mathrm{OH}$,$\mathrm{COOH},-\mathrm{CO},-\mathrm{CH}$ functional groups exist in surface of the biochar, which may be involved in MB binding. The surface complexation is quite important function in the adsorption process between $\mathrm{MB}$ and biochar, containing hydrogen bonding and electronic attraction. Additionally, ion exchange plays an important role in MB adsorption onto biochar. The deionized water was regarded as contrast and the heavy ions $\left(\mathrm{Ca}^{2+}\right.$, $\mathrm{Na}^{+}, \mathrm{K}^{+}$and $\mathrm{Mg}^{2+}$ ) from the biochars were released in the mixtures of water and biochar, especially the $\mathrm{Ca}^{2+}$ 


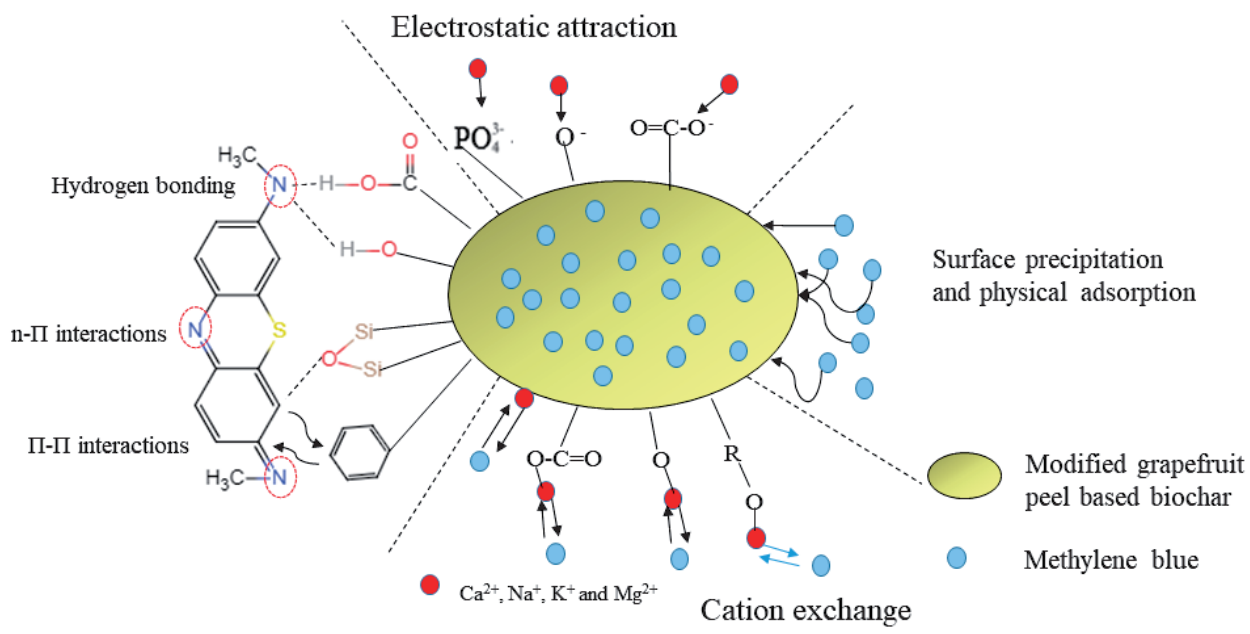

Fig. 13. Interaction mechanisms in the biochar-MB system.

and $\mathrm{K}^{+}$ions which more participates the ion exchange process.

The regeneration of the biochar plays an important role to assess the possibility for large-scale utilization. The adsorption cycles of MB were carried out thrice by eluent of $0.1 \mathrm{~mol} / \mathrm{L} \mathrm{HCl}$. Fig. 14 exhibits the removal efficiencies of the first regeneration cycle, second regeneration cycle, third regeneration cycle and fourth regeneration cycle are $93.12 \%, 91.15 \%, 87.65 \%$ and $63.81 \%$, respectively. The result reveals that the gradual decline in the adsorption capacity of the modified biochar for MB occurred for four consecutive adsorption cycles and the dramatic decline was observed after four regeneration cycles. It is thus indicated that the modified pomelo peel based biochar can be regenerated and have application prospect as a useful adsorbent for water treatment.

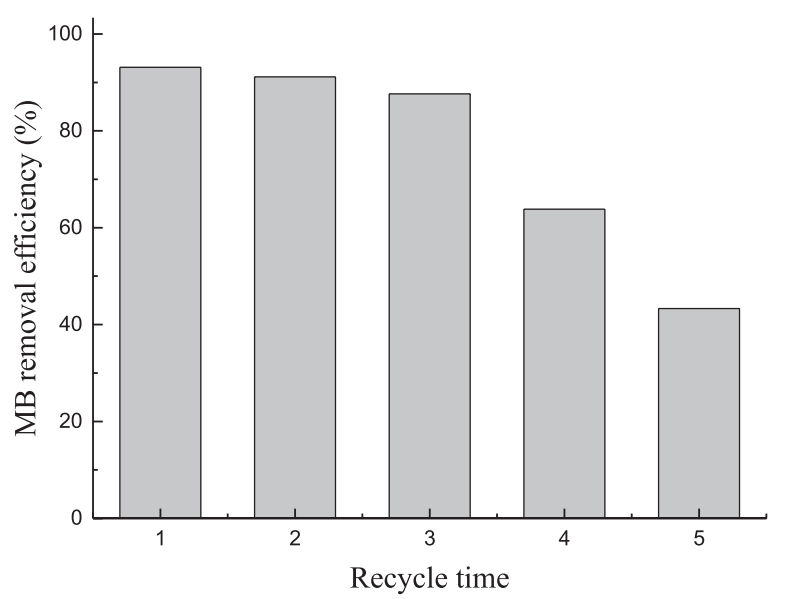

Fig. 14. Evolution of regeneration efficiency after each regeneration cycle (the biochar dosage $=0.5 \mathrm{~g}$; temperature $=25^{\circ} \mathrm{C}$; contact time $=60 \mathrm{~min}$; initial $\mathrm{MB}$ concentration $=100 \mathrm{mg} /$ Land initial $\mathrm{pH}=7$ ).

\section{Conclusions}

The current work compared that the biochar prepared by different doses of the modified biochar $(0.025,0.5,1.0$ and $1.5 \mathrm{~g})$, pyrolysis temperature $\left(450^{\circ} \mathrm{C}, 500^{\circ} \mathrm{C}\right.$ and $550^{\circ} \mathrm{C}$ ) and atmosphere (vacuum and nitrogen) was used to remove $\mathrm{MB}$ from simulated wastewater. The results showed that $0.05 \mathrm{~g}$ modified pomelo peel based biochar prepared under $500^{\circ} \mathrm{C}$ and vacuum was selected preliminarily in this study. The bulk structure and surface rougher of the biochar increased with the rising of calcination temperature. The prepared materials contained a large number of active functional groups such as lignin, cellulose and hemicellulose. The specific surface area of the calcinated materials at $450^{\circ} \mathrm{C}, 500^{\circ} \mathrm{C}$ and $550^{\circ} \mathrm{C}$ was $2.511,3.353$ and $4.344 \mathrm{~m}^{2} / \mathrm{g}$, respectively, which were belong to mesoporous materials $(2-50 \mathrm{~nm})$. It seemed that ANN-PSO was appropriate to model and predict the parameters of $\mathrm{MB}$ removal by the fabricated biochar in comparison with RSM. The maximum removal efficiency of MB was $89.72 \%$ by ANN-PSO, corresponding that experimental conditions were as follows: temperature $=34.63^{\circ} \mathrm{C}$, contact time $=$ $80.00 \mathrm{~min}$, initial $\mathrm{MB}$ concentration $=169.7 \mathrm{mg} / \mathrm{L}$ and initial $\mathrm{pH}=7$. Under these conditions, the actual removal efficiency was $87.96 \%$, and the absolute error was $1.76 \%$. The MB removal process can be described with pseudo-second order kinetics model and Langmuir isotherm. Thermodynamics study exhibited that the adsorption process was spontaneous, endothermic and entropy-driven, and the adsorption process involved electrostatic interaction, ion exchange, chemical action and physical behavior. In summary, it is thus indicated that the modified pomelo peel based biochar can be regenerated and has application prospect as a useful adsorbent for water treatment. 


\section{Author Contributions}

W. W. and X. W. designed the research; W. W. X.W. and S. L. wrote the paper and performed the experiments and data analysis.

\section{Acknowledgments}

This work was financially supported by the scientific research funds of Guiyang University (GYU-KY-2021) and Funds of the Youth Growth S\&T Personnel Foundation of Guizhou Education Department (No.KY [2020]078).

\section{Data Availability}

The data used to support the findings of this study are available from the corresponding author upon request.

\section{Conflict of Interest}

The authors declare no competing interests.

\section{References}

1. FURIAN A.F., FIGHERA M.R., OLIVEIRA M.S. Methylene blue prevents methylmalonate-induced seizures and oxidative damage in rat striatum. Neurochem. Int., 50 (1), 164, 2007

2. FUNG J.C.L., CHO E.Y.P. Methylene blue promotes survival and GAP-43 expression of retinal ganglion cells after optic nerve transection. Life Sci. 262, 118462 , 2020.

3. HRUSHESKY W. Methylene blue protects intestinal mucosa from free radical-mediated sublethal radiation damage. Free Radical Bio. Med. 5 (4), 207, 1988.

4. WANG Y., HUANG X., LV X., SUN J., ZHENG R., HU $\mathrm{K}$. The Metabolism of Methylene Blue and Its Derivatives in Japanese Eel (Anguilla Japonica). J. Ocean Univ. China 19, 653, 2020.

5. PRADEL J.S., TONG W.G. Determination of malachite green, crystal violet, brilliant green and methylene blue by micro-cloud-point extraction and nonlinear laser wave-mixing detection interfaced to micellar capillary electrophoresis. Anal. Methods-UK, 9 (45), 6411, 2017.

6. RANOUX A., DJANASHVILI K., ARENDS I.W.C.E., HANEFELD U. Methylene Blue as a Photosensitizer and Redox Agent: Synthesis of 5-Hydroxy-1H-pyrrol-2 (5H)ones from Furans. Angew. Chem. Int. Edit. 127 (4), 6381, 2015.

7. LACHANT N.A., GOTTLIEB A.J., DIFINO S.M., LANDAW S.A., TANAKA K.R. Increased heinz body formation and impaired erythrocyte pentose phosphate shunt function during pregnancy. Am. J. Hematol. 18 (2), 131, 2010.

8. FRANCESCANGELI J., VAIDA S., Bonavia A.S. Perioperative Diagnosis and Treatment of Serotonin
Syndrome Following Administration of Methylene Blue American Journal of Case Reports 17, 347, 2016.

9. XIA Y., YAO Q., ZHANG W., ZHANG Y., ZHAO M. Comparative adsorption of methylene blue by magnetic baker's yeast and EDTAD-modified magnetic baker's yeast: Equilibrium and kinetic study. Arab. J. Chem. 12 (8), 2448, 2019.

10. WANG N., CHEN J., WANG J.N., FENG J.T., YAN W. Removal of methylene blue by Polyaniline/ $\mathrm{TiO}_{2}$ hydrate: Adsorption kinetic, isotherm and mechanism studies. Powder Technol. 347, 93, 2019.

11. GHOSH R.K., RAY D.P., DEBNATH S., TEWARI A., DAS I. Optimization of process parameters for methylene blue removal by jute stick using response surface methodology. Environ. Prog. Sustain. 38 (5), 1, 2019.

12. ZULFIKAR M.A., SETIYANTO H., RUSNADI M., SOLAKHUDIN L. Rubber seeds (Hevea brasiliensis): an adsorbent for adsorption of Congo red from aqueous solution. Desalin. Water Treat. 56 (11), 2976, 2015.

13. VILAR V.J.P., BOTELHO C.M.S., RUI A.R.B. Methylene blue adsorption by algal biomass based materials: Biosorbents characterization and process behaviour. J. Hazard. Mater. 147 (1-2), 120, 2007.

14. VIJAYARAGHAVAN J., BHAGAVATHI PUSHPA T., SARDHAR BASHA S.J. VIJAYARAGHVANi K., JEGAN J. Evaluation of Red Marine Alga Kappaphycus alvarezii as Biosorbent for Methylene Blue: Isotherm, Kinetic, and Mechanism Studies. Sep. Sci. Technol. 50 (8), 1120, 2015.

15. ZHANG P., O'CONNOR D., WANG Y. JIANG L., HOU D. A green biochar/iron oxide composite for methylene blue removal. J. Hazard. Mater. 384, 121286, 2019.

16. FAN S., TANG J., WANG Y., LI H., ZHANG H., TANG J., WANG Z., LI X. Biochar prepared from co-pyrolysis of municipal sewage sludge and tea waste for the adsorption of methylene blue from aqueous solutions: Kinetics, isotherm, thermodynamic and mechanism. J. Mol. Liq. 220, 432, 2016.

17. LONAPPAN L., ROUISSI T., DAS R.K. Adsorption of methylene blue on biochar microparticles derived from different waste materials. Waste Manage. 49 (3), 537, 2016.

18. CAPONI N., COLLAZZO G.C., SALLA J.D.S., BRAR S.K. Optimisation of crystal violet removal onto raw kaolin using response surface methodology. International Journal of Environmental Technology and Management, $22(2 / 3), 85,2019$.

19. GOHARI M., RAHMAN R., TAHMASEBI M. Application of artificial neural network and response surface methodology for the removal of crystal violet by zinc oxide nanorods loaded on activate carbon: kinetics and equilibrium study. J. Taiwan Inst. Chem. E., 59 (33), 210, 2016.

20. SHIN Y., KIM Z., YU J., KIM J., HWANG S. Development of $\mathrm{NO}_{\mathrm{x}}$ reduction system utilizing artificial neural network (ANN) and genetic algorithm (GA). J. Clean. Prod. 232 (9), 1418, 2019.

21. JUN L.Y., KARRI R.R., YON L.S., MUBARAK N.M., BING C.H., MOHAMMAD K., JAGADISH P., ABDULLAH E.C. Modeling and optimization by particle swarm embedded neural network for adsorption of methylene blue by jicama peroxidase immobilized on buckypaper/polyvinyl alcohol membrane. Environ. Res. 183, 109158, 2020.

22. QI J.M , HOU Y., HU J.W., RUAN W.Q., WEI, X.H. Decontamination of methylene Blue from simulated wastewater by the mesoporous $\mathrm{rGO} / \mathrm{Fe} / \mathrm{Co}$ nanohybrids: 
Artificial intelligence modeling and optimization. Mater. Today Commun. 24, 100709, 2020.

23. CHEN C., CHENG T., WANG Z.L., HAN, C.H. Removal of $\mathrm{Zn}^{2+}$ in aqueous solution by Linde $\mathrm{F}(\mathrm{K})$ zeolite prepared from recycled fly ash. J. Indian Chem. Soc. 91, 1, 2014.

24. XIE W.F., CHENG T., CHEN C., SUN C., QI L., ZHANG Z.M. Optimizing and modelling $\mathrm{Cu}$ (II) removal from simulated wastewater using attapulgite modified with Keggin ions with the aid of RSM, BP-ANN and GA-BP. Desalin. Water Treat. 207, 270, 2020.

25. WU X.L., HU J.W., QI J.M., HOU Y., WEI X.H. Graphenesupported ordered mesoporous composites used for environmental remediation: A review. Sep. Purif. Technol. 239, 116511, 2020.

26. THARWAT A., ELHOSENY M., HASSANIEN A.E., GABEL T., KUMAR A. Intelligent Bézier curve-based path planning model using Chaotic Particle Swarm Optimization algorithm. Cluster Comput. 22 (4), 4745, 2019.

27. DEHKHODA A.M., ELLIS N., GYENGE E. Effect of activated biochar porous structure on the capacitive deionization of $\mathrm{NaCl}$ and $\mathrm{ZnCl}_{2}$ solutions. Micropor. Mesopor. Mat. 224, 217, 2016.

28. HE Q.X., CHEN Z.L. Characterization and kinetics of biochar prepared from pomelo peel for adsorption of phenol. Chinese Journal of Environmental Engineering 8 (9), 3853, 2014 [In Chinese].

29. GUO X.H., KANG K., YU X.N., SHANG G.Y., QIU L. Study on physicochemical properties of magnetic modified biochar derived from pyrolysis of pomelo peel and apricot kernel shell. Transactions of the Chinese Society of Agricultural Engineering 34 (Z), 164, 2018 [In Chinese].

30. HOU J., HUANG L., YANG Z., ZHAO Y.Q., DENG C.R., CHEN Y.C., LI X. Adsorption of ammonium on biochar prepared from giant reed. Environ. Sci. Pollut. R. 23 (19), 19107, 2016.

31. LI D.C., DING J., QIAN T.T., ZHANG S., JIANG H. Preparation of High Adsorption Performance and Stable Biochar Granules by $\mathrm{FeCl}_{3}$-Catalyzed Fast Pyrolysis. RSC Adv. 6 (15), 12226, 2016.

32. MANYA J.J., ROCA F.X., PERALES J.F. TGA study examining the effect of pressure and peak temperature on biochar yield during pyrolysis of two-phase olive mill waste. J. Anal. Appl. Pyrol. 103 (9), 86, 2013.

33. WANG L.P., LIU J.J., SHEN X.L., LI X.Y. Optimization of adsorption of methylene blue by attapulgite using response surface methodology. Chinese Journal of Environmental Engineering, 10 (9), 4912, 2016.

34. WU X.L., HUANG X.F., ZHANG Z.M. Influencing factors of Cd (II) removal from aqueous solution by $\mathrm{Fe}_{3} \mathrm{O}_{4} /$ GO. China Environmental Science, 39 (6), 2411, 2019 [In Chinese].

35. KHOSRAVI M., ARABI S. Application of response surface methodology (RSM) for the removal of methylene blue dye from water by nano zero-valent iron (NZVI). Water Sci. Technol., 74 (2), 343, 2016.

36. SAPAWE N., JALIL A.A., TRIWAHYONO S., SHAH M.I.A., JUSOH R., SALLEH N.F.M., HAMEED B.H., KARIM A.H. Cost-effective microwave rapid synthesis of zeolite $\mathrm{NaA}$ for removal of methylene blue. Chem. Eng. J., 229, 388, 2013.

37. SADHUKHAN B., MONDAL N.K., CHATTORAJ S. Biosorptive removal of cationic dye from aqueous system: a response surface methodological approach. Clean Technol. Environ. 16 (6), 1015, 2014.
38. FENG H.M. Self-generation RBFNs using evolutional PSO learning. Neurocomputing 70 (1-3), 241, 2006.

39. ZHAO S., ZHAO Z. A Comparative Study of Landslide Susceptibility Mapping Using SVM and PSO-SVM Models Based on Grid and Slope Units. Math. Probl. Engin. 2021 (3), 1, 2021.

40. LIU K.F., XI Z.W., HUANG L.N., HUI F.L. Optimization of High Cell Density Fermentation of Saccharomyces boulardii for Enhanced Biomass Production. Food Science, 40 (8), 56, 2019 [In Chinese].

41. LI K.X., ZHAN P., TIAN H.L., WEI Z.S., WANG P., ZHANG F. Optimization of processing conditions of garlic flavoring powder based on GA-BP neural network. Journal of Chinese Institute of Food Science and Technology, 20 (10), 156, 2020 [In Chinese].

42. CHEN C., CHENG T., SHI Y.S., TIAN Y. Adsorption of $\mathrm{Cu}$ (II) from aqueous solution on fly ash based linde $\mathrm{F}(\mathrm{K})$ Zeolite, Iran. J. Chem. Chem. Eng. 33, 29, 2014.

43. CHEN C., CHENG T., ZHANG X., WU R., WANG Q. Synthesis of an effcient $\mathrm{Pb}$ adsorption nano-crystal under strong alkali hydrothermal environment using a gemini surfactant as directing agent. J. Chem. Soc. Pak. 41, 1034, 2019.

44. CHENG T., CHEN C., TANG R., HAN C.H., TIAN $\mathrm{Y}$. Competitive adsorption of $\mathrm{Cu}, \mathrm{Ni}, \mathrm{Pb}$ and $\mathrm{Cd}$ from aqueous solution onto fly ash-based Linde $\mathrm{F}(\mathrm{K})$ zeolite. J. Chem. Chem. Eng. 37, 61, 2018.

45. YAO N., CHEN C., LI D.J., HU Y.L. Cobalt nanoparticles embedded over periodic mesoporous organosilica functionalized with benzotriazolium ionic liquid for efficient and heterogeneous catalytic transformation of carbon dioxide to cyclic carbonates. J. Environ. Chem. Eng., 8, 103953, 2020.

46. DENG H., YANG L., TAO G., DAI J. Preparation and characterization of activated carbon from cotton stalk by microwave assisted chemical activationApplication in methylene blue adsorption from aqueous solution. J. Hazard. Mater., 166, 1514, 2009.

47. AUTA M., HAMEED B.H. Optimized waste tea activated carbon for adsorption of Methylene Blue and Acid Blue 29 dyes using response surface methodology. Chem. Eng. J. 175, 233, 2011

48. FOO K.Y., HAMEED B.H. Adsorption characteristics of industrial solid waste derived activated carbon prepared by microwave heating for methylene blue. Fuel Process. Technol., 2012, 99, 103, 2012.

49. FOO K.Y., HAMEED B.H. A rapid regeneration of methylene blue dye-loaded activated carbons with microwave heating. J. Anal. Appl. Pyrol. 98, 123, 2012.

50. ZHANG W., ZHANG L.Y., ZHAO X.J., ZHOU Z. Citrus pectin derived porous carbons as a superior adsorbent toward removal of methylene blue. J. Solid State Chem., 243, 101, 2016.

51. MARRAKCHI F., AUTA M., KHANDAY W.A., HAMEED B.H. High-surface-area and nitrogen-rich mesoporous carbon material from fishery waste for effective adsorption of methylene blue. Powder Technol., 321, 428, 2017.

52. ISLAM M.A., AHMED M.J., KHANEY W.A., ASIF M. HAMEED B.H. Mesoporous activated coconut shell-derived hydrochar prepared via hydrothermal carbonization- $\mathrm{NaOH}$ activation for methylene blue adsorption. J. Environ. Manag., 203, 237, 2017.

53. ANGELA D. SUMALINOG, G. CAPAREDA S.C. DANIEL M., DE LUNA, G. Evaluation of the effectiveness and mechanisms of acetaminophen and methylene blue dye 
adsorption on activated biochar derived from municipal solid wastes. J. Environ. Manag., 210, 255, 2018.

54. FAN M., HU J., CAO R., XIONG K., WEI X. Modeling and prediction of copper removal from aqueous solutions by $\mathrm{nZVI} / \mathrm{rGO}$ magnetic nanocomposites using ANN-GA and ANN-PSO. Sci. Rep. 7, 18040, 2017.

55. SHI X., RUAN W., HU J., FAN M., CAO R., WEI X. Optimizing the removal of rhodamine $\mathrm{B}$ in aqueous solutions by reduced graphene oxide-supported nanoscale zerovalent iron (nZVI/rGO) using an artificial neural network-genetic algorithm (ANN-GA). Nanomaterials, 7, 134, 2017.

56. JIAN D.Y., YU J., YE Z.X., WEI B., YANG Z.R., YANG L. Adsorption and mechanism of methylene blue from water by magnetic nanocomposites. China Environmental Science 36 (6), 1763, 2016 [In Chinese].

57. ZHU Y., YI, B.J., YUAN Q.X., WU Y.L., WANG M., YAN S.P. Removal of methylene blue from aqueous solution by cattle manure-derived low temperature biochar. RSC Adv. 8 (36), 19917, 2018. 